\title{
A hole in the nematosphere: tardigrades and rotifers dominate cryoconite hole environment, whereas nematodes are missing
}

\author{
Published in the Jourlan of Zoology at \\ https://zslpublications.onlinelibrary.wiley.com/doi/full/10.1111/jzo.12832
}

\begin{abstract}
Zawierucha, K., Porazinska, D.L., Ficetola, G.F., Ambrosini, R., Baccolo, G., Buda, J., Ceballos, J.L., Devetter, M., Dial, R., Franzetti, A., Fuglewicz, U., Gielly, L., Łokas12, E., Janko, K., Jaromerska, T., Koscinski, A., Kozłowska, A., Ono, M., Parnikoza, I., Pittino, F., Poniecka, E., Sommers, P., Schmidt, K.S., Shain, D., Sikorska, S., Uetake, J., Takeuchi, N., 2020. A hole in the nematosphere: tardigrades and rotifers dominate the cryoconite hole environment, whereas nematodes are missing. Journal of Zoology, https://doi.org/10.1111/jzo.12832
\end{abstract}

Krzysztof Zawierucha ${ }^{1 *}$, Dorota L. Porazinska ${ }^{2}$, G. Francesco Ficetola ${ }^{3,4}$ Roberto Ambrosini $^{3}$, Giovanni Baccolo ${ }^{5}$, Jakub Buda ${ }^{1}$, Jorge Luis Ceballos ${ }^{6}$, Miloslav Devetter ${ }^{7,8}$, Andrea Franzetti ${ }^{9}$, Aleksandra Fuglewicz ${ }^{10}$, Ludovic Gielly ${ }^{4}$, Edyta Lokas $^{11}$, Karel Janko ${ }^{12,13}$, Tereza Jaromerska ${ }^{14}$, Albert Kościński ${ }^{15}$, Masato Ono ${ }^{16}$, Ivan Parnikoza ${ }^{17,18}$, Francesca Pittino $^{9}$, Ewa Poniecka ${ }^{19}$, Pacifica Sommers ${ }^{20}$, Steven K. Schmidt ${ }^{20}$, Daniel Shain ${ }^{21}$, Jun Uetake $^{22}$, Nozomu Takeuchi ${ }^{23}$

\footnotetext{
${ }^{1}$ Department of Animal Taxonomy and Ecology, Adam Mickiewicz University, Poznań, Uniwersytetu Poznańskiego 6, 61-614 Poznań, Poland, e-mail: k.p.zawierucha@gmail.com; ${ }^{2 D}$ Department of Entomology and Nematology, University of Florida, Gainesville, FL, USA; ${ }^{3}$ Department of Environmental Science and Policy, University of Milan, Via Celoria 26, 20131 Milan, Italy; ${ }^{4}$ University Grenoble Alpes, CNRS, Univ. Savoie Mont Blanc, LECA, Laboratoire d'Ecologie Alpine, F-38000 Grenoble; ${ }^{5}$ Earth and Environmental Science Department, University of Milano-Bicocca, 20126, Milan, Italy; ${ }^{6}$ Instituto de Meteorologl'a, Hidrologi'a y Estudios Ambientales, Bogota', Colombia; ' Institute of soil Biology, Biology Centre CAS, Na Sádkách 7, 37005 České Budějovice, Czech Republic; ${ }^{8}$ Centre for Polar Ecology, Faculty of Science, University of South Bohemia, Na Zlaté Stoce 3, 37005 České Budějovice, Czech Republic; ${ }^{9}$ Department of Earth and Environmental Sciences (DISAT), University of Milano-Bicocca, Piazza della Scienza, 1 - 20126 Milano, Italy; ${ }^{10}$ Skarbowców 89/6, 53-025 Wrocław, Poland; "Institute of Nuclear Physics Polish Academy of Sciences, Department of Mass Spectroscopy, Radzikowskiego 152, Kraków, Poland; ${ }^{12}$ Laboratory of Fish Genetics, Institute of Animal Physiology and Genetics, Academy of Sciences of the Czech Republic, Libechov, Czech Republic; ${ }^{13}$ Department of Biology and Ecology, Faculty of Science, University of Ostrava, Chittussiho 10, Ostrava, Czech Republic; ${ }^{14}$ Department of Ecology, Faculty of Science, Charles University, Viničná 7, CZ-128 44, Praha 2, Czech Republic; ${ }^{15}$ Wietrzna 24/153-024 Wrocław, Poland; ${ }^{16}$ Graduate School of Science and Engineering, Chiba University; ${ }^{17}$ Sate Institution National Antarctic Center of Ministry of Education and Science of Ukraine, 16 Taras Shevchenko Blvd., 01601, Kyiv, Ukraine; ${ }^{18}$ Institute of Molecular Biology and Genetics, National Academy of Sciences of Ukraine, 150, Zabolotnogo Str., Kyiv, Ukraine, 03143; ${ }^{19}$ School of Earth and Ocean Sciences, Cardiff University, Cardiff, UK; ${ }^{20}$ Ecology and Evolutionary Biology Department, University of Colorado, Boulder, CO, USA; ${ }^{21}$ Biology Department, Rutgers, The State University of New Jersey, 315 Penn St., Camden, NJ 08102, United States; ${ }^{22}$ The Arctic Environment Research Center, National Institute of Polar Research, 10-3 Midoricho, Tachikawa, Tokyo, 190-8518, Japan; ${ }^{23}$ Department of Earth Sciences, Graduate School of Science, Chiba University, Chiba, Japan.
} 


\begin{abstract}
The worldwide distribution of microinvertebrates on glaciers, the coldest biome, is poorly known. Owing to their tolerance to hostile conditions, small size and dispersal abilities, nematodes, tardigrades and rotifers are considered cosmopolitan and together inhabit various ecosystems. In this study, we investigated their global distribution in cryoconite holes - a type of freshwater reservoir forming directly in the glacial ice that creates biodiversity hotspots on glaciers. We analysed cryoconite samples (using classical microscopic observations and environmental DNA metabarcoding) from 42 glaciers located around the world (the Arctic, Subarctic, Scandinavia, the Alps, the Caucasus, Siberia, Central Asia, Africa, South America and Antarctica), as well as using literature data. Samples from Antarctic, Karakoram and the Alps were analysed using next-generation sequencing (NGS) and classical observations under microscopes, while all other samples were analysed by microscope alone. Three general outcomes were found: (1) tardigrades and rotifers represented the most common invertebrates in cryoconite holes; (2) tardigrades and rotifers often coexisted together, with one or the other dominating, but the dominant taxon varied by region or by glacier; (3) nematodes - the most abundant, hyperdiverse and widespread metazoans on Earth, including in environments surrounding and seeding glacial surfaces - were consistently absent from cryoconite holes. Despite the general similarity of environmental conditions in cryoconite holes, the distribution of tardigrades and rotifers differed among glaciers, but not in any predictable way, suggesting that their distribution mostly depended on the random dispersal, extreme changes of supraglacial zone or competition. Although nematodes have been found in supraglacial habitats, cryoconite hole environments seem not to provide the necessary conditions for their growth and reproduction. Lack of physiological adaptations to permanently low temperatures $\left(\sim 0^{\circ} \mathrm{C}\right)$ and competition for different food resources in the cryoconite hole environment may explain the absence of nematodes in cryoconite holes.
\end{abstract}

Key words: Cryoconite holes, Ecological selection, Extremophiles, Distribution, Glaciers, Nematoda, Psychrophiles, Rotifera, Supraglacial, Tardigrada, 


\section{Introduction}

The spatial distribution of life forms has been studied for centuries (Aristotle, 350 B.C.E.; Darwin, 1859; MacArthur \& Willson, 1967). However, historically, these biogeographical surveys have been limited to macroorganisms. The emergence of new optical and molecular tools now allows the pursuit of similar questions for microorganisms, including single-cell microbes and multicellular micrometazoans (Nkem et al., 2006a, 2006b; Guil, Sánchez-Moreno \& Machordom, 2009; Velasco-Castrillón, Gibson \& Stevens, 2014; Darcy et al., 2018; VelascoCastrillón, Hawes \& Stevens, 2018; Zawierucha et al., 2018b). Recent studies show that the distributions of micrometazoan taxa can be related to physiological and dispersal constraints (Nkem et al., 2006a, 2006b; Dial et al., 2012; Shain et al., 2016; Zawierucha et al., 2018b; Zawierucha et al., 2019b), competition (Shaw et al., 2018), geographical barriers (Jørgensen, Møbjerg \& Kristensen, 2007; Czechowski et al., 2016) and to ongoing shifts in environmental conditions (Andriuzzi et al., 2018).

Since microinvertebrates (i.e. tardigrades, rotifers and nematodes) display similar size, dormancy and dispersal characteristics to unicellular organisms (Crowe \& Madin, 1974; Sohlenius, 1977; Ramazzotti \& Maucci, 1983), they may be expected to show worldwide distribution that is similar to microbes (Fontaneto, 2019). However, the long-standing expectation of cosmopolitan distributions for microbes - the 'Everything small is everywhere' hypothesis (Liu et al., 2017; Segawa et al., 2017, 2018; Fontaneto, 2019) - has been refuted for some of microinvertebrates by contemporary inventories of species diversity that reveal examples of endemism (Faurby et al., 2012; Cesari et al., 2016; Fontaneto, 2019). The evidence for endemism largely applies to higher precision taxonomic categories, like genus and species (Forró et al., 2008), although not always, while cosmopolitan distributions apply to more coarse categories, like phylum and class. However, not all taxa at low taxonomic resolution are cosmopolitan. The phylum Onychophora (velvet worms), for example, inhabits the tropics, while the microinvertebrate phylum Loricifera (brush heads) await confirmation of their distribution (Monge-Najera, 1995; Kristensen, 2002).

A recent review (Fontaneto, 2019) of the distribution of limno-terrestrial rotifers, tardigrades and nematodes found a wide array of geographical ranges from worldwide, to biogeographically restricted, to completely endemic. Unfortunately, typical studies of distribution patterns in microinvertebrates involve comparisons across very different habitats (e.g. soil, bryophytes or lichens, freshwater lakes, puddles) distributed across different biogeographical realms (Segers, 2008; Kaczmarek, Michalczyk, \& McInnes, 2016; van den Hogen et al., 2019). This lack of ecological focus can hamper biogeographical conclusions and generalizations. A worldwide analysis of microinvertebrates that focuses on a specific habitat characterized by a specific thermal regime and other environmental conditions is currently absent.

Terrestrial ecosystems constitute $30 \%$ of Earth's surface. Although $10 \%$ of that is covered by glaciers and ice sheets, our knowledge about microinvertebrate diversity in these parts of the cryosphere is very incomplete. While polar terrestrial habitats have been the subject of many microinvertebrate diversity studies (Wu et al., 2011; Coulson et al., 2014; Iakovenko et al., 2015), glacial habitats have not been well characterized (Zawierucha et al., 2015; Zawierucha et al., 2019a). During the melt season, warm temperatures and solar radiation transform glacial snow into liquid water, thereby providing a suitable environment for psychrophilic organisms (Hodson et al., 2008; Cook et al., 2016). Among habitats associated with glaciers, cryoconite holes - water-filled reservoirs ( $20-50 \mathrm{~cm}$ deep) in the glacial ice (Wharton et al., 1985; 
Hodson et al., 2008; Stibal et al., 2010; Cook et al., 2016) - are known glacier biodiversity hotspots. The formation of these meltwater holes results from sediments (soil, rock fragments and mineral dust along with cryophilic organisms) that absorb solar radiation and so melt into the ice (Hodson et al., 2008; Takeuchi, Nishiyama, \& Li, 2010; Cook et al., 2016; Uetake et al., 2016). Cryoconite holes are inhabited principally by bacteria (both heterotrophic and photoautotrophic), algae and microinvertebrates (e.g. tardigrades and rotifers) (Porazinska et al., 2004; Zawierucha et al., 2015; Uetake et al., 2016; Zawierucha et al., 2018a, 2018b). The photosynthetic rates and organic matter content in cryoconite holes are comparable to other nutrient-poor freshwater ecosystems, such as stony-bottom oligotrophic lakes (Säwström et al., 2002; Peters \& Traunspurger, 2005).

Despite more than a century of research on cryoconite holes (Drygalski, 1897), the global biogeography of microinvertebrates - top consumers within cryoconite holes - remains poorly known; most studies generally focus on the worldwide distributions of bacteria and algae (Mueller et al., 2001; Liu et al., 2017; Segawa et al., 2017, 2018; Darcy et al., 2018). Microinvertebrates of cryoconite holes feed on these producers and on dead organic matter as herbivores, microbivores and filter feeders (Takeuchi \& Kohshima, 2004; Vonnahme et al., 2016; Zawierucha et al., 2016). Among microinvertebrates observed in cryoconite holes, studies indicate a ubiquitous presence of tardigrades and rotifers, yet an anecdotal absence of nematodes (Porazinska et al., 2004; Zawierucha et al., 2015). This absence of nematodes is very surprising, given their prevalence across all of Earth's aquatic and terrestrial habitats, including the most extreme (e.g. Borgonie et al., 2011; Grzelak et al., 2016; Andriuzzi et al., 2018; van den Hoogen et al., 2019).

Nematodes have been reported in supraglacial gravel in the Alps by Azzoni et al. (2015) and in moss balls (so-called 'glacier mice') in Iceland by Coulson \& Midgley (2012). Additionally, Schwarz et al. (1993) found a high abundance of nematodes in mosses associated with a stream located near Taylor Glacier in the McMurdo Dry Valleys of Antarctica. Nematodes have also been detected within a cryoconite hole in the McMurdo Dry Valley using classical microscopy, but on a single occasion (Mueller et al., 2001). Others (Christner, Kvitko, \& Reeve, 2003; Sommers et al., 2018) detected nematodes in Dry Valley glacier cryoconite holes using genetic barcoding, but not corroborated by microscopic inspection. Subsequent microscopic examination and high-throughput sequencing of cryoconite from holes on the same glaciers have failed to detect any further evidence of nematodes, neither living nor dead (Porazinska et al., 2004; Sommers et al., 2019). Taken together, these studies suggest that although cryoconite holes may be seeded from environments containing nematodes, they do not thrive there. Moreover, in Norway and the Alps, remnants of various arthropods in cryoconite holes were detected with microscopy, but nematodes were not (Dastych, 2019; Zawierucha et al., 2019a).

As rotifers, tardigrades and nematodes exhibit similar life and feeding strategies (Sohlenius, 1979; Altiero \& Rebecchi, 2001; Michiels \& Traunspurger, 2005), occupy similar habitats (Sohlenius, 1977; Janiec, 1996; Sohlenius, Boström, \& Jönsson, 2004) and could be passively dispersed by the same mechanisms into cryoconite holes, a reasonable null hypothesis would claim all three phyla should co-occur in cryoconite holes. Here, we synthesize original and previously published data to examine the distribution of microinvertebrates in cryoconite holes on glaciers around the world. 


\section{Materials and methods Original data}

Cryoconite material was collected from cryoconite holes across a wide variety of glaciers differing in their (1) morphology (e.g. tidewater vs. valley), (2) thermal regime (i.e. polythermal vs. cold-base vs. temperate), (3) light and temperature [e.g. seasonal cycles (polar) vs. daily cycles (temperate)], and (4) elevation (i.e. terminating in the sea vs. high mountains up to 5200 $\mathrm{m}$ a.s.1.). A total of 42 glaciers (Fig. 1) were sampled in the Arctic [Greenland, Svalbard (Spitsbergen, Nordaustlandet)], the Subarctic (Alaska), Scandinavia (Norway, Sweden), the Alps, the Caucasus, Siberia, Central Asia (the Karakoram, Pamir, Tien and Quilian Shan, Himalaya), Africa (Tanzania), South America (Colombia, Chile), Maritime Antarctica (Anvers Island, King George Island) and Continental Antarctica (McMurdo Dry Valleys). We sampled a wide range of cryoconite hole depths to reflect the variability in niche stability. The deepest holes were $>60 \mathrm{~cm}$ deep with relatively stable water bodies; the shallowest were to $<5 \mathrm{~cm}$ deep and subject to flooding and freeze/thaw cycles. Details of sampled cryoconite holes are provided in Supporting Information Table S1. Information on cryoconite holes from other sites was added by reviewing the published literature (Supporting Information Figure S1; Supporting Information Table S1). Data on the area and depth of cryoconite holes in particular regions and glaciers are available in Zawierucha et al. (2018a) for SW Greenland, Zawierucha et al. (2019c) and Lokas et al. (2016) for Svalbard, Zawierucha et al. (2019a) for the Alps, Takeuchi et al. (2000) for Himalaya, Buda et al. (2020) for Maritime Antarctica, and Porazinska et al. (2004) and Sommers et al. (2019) for Continental Antarctic.

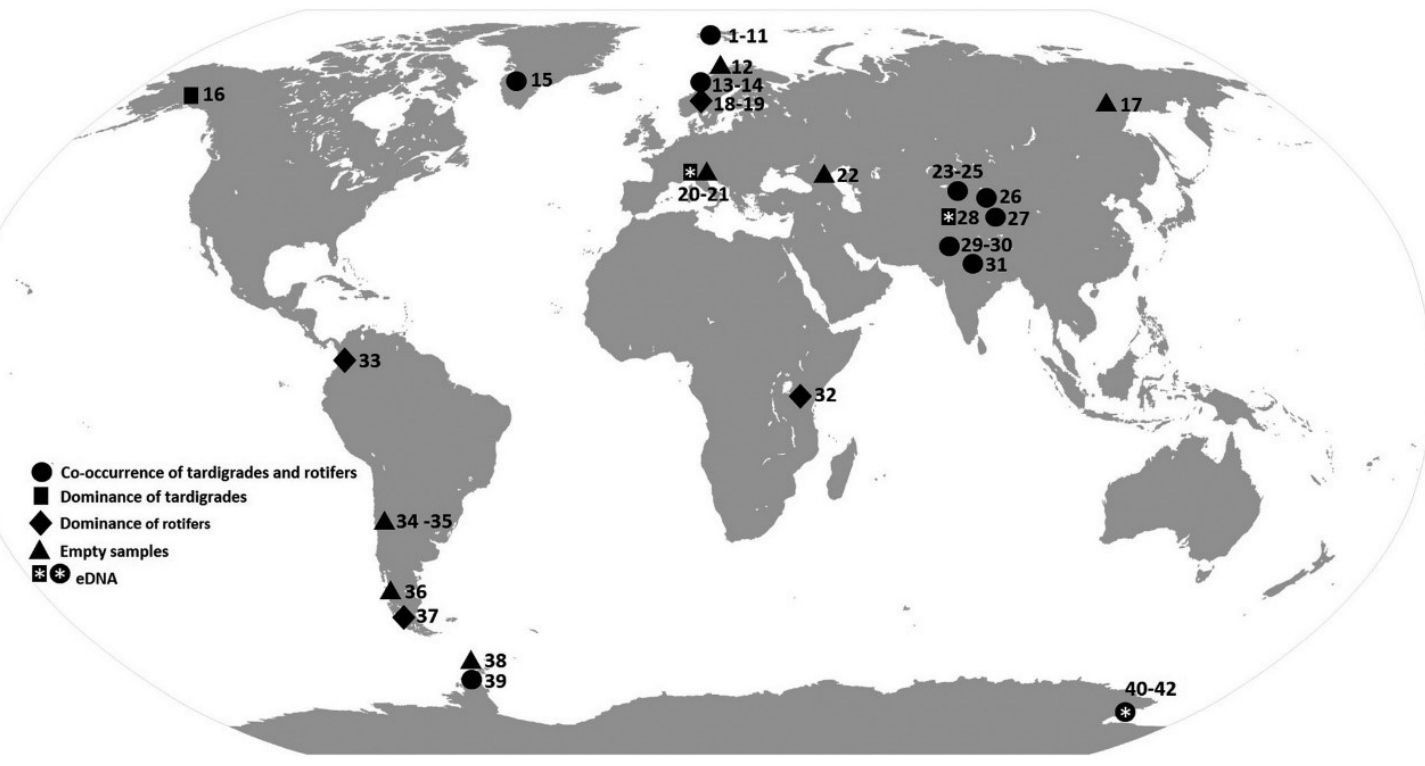

Figure 1 - List of sampled glaciers (original data). Svalbard: Nordaustlandet: 1 - Area of Goosbukta, 2 Dunerbreen, 3 - Nordre Franklinbreen, Spitsbergen: 4. Midre Lovénbreen, 5 - Svenbreen, 6 - Ebbabreen, 7 Nordenskiöldbreen, 8 - Longyearbreen, 9 - Larsbreen, 10 - Werenskioldbreen, 11 - Hansbreen, Scandinavia: 12 - Storglaciären (Sweden), 13 - Svartisen, 14 - Okstindbreen (Norway), Greenland: 15 - Dark zone of Greenland Ice Sheet, Alaska: 16 - Gulkana Glacier, Siberia: 17 - Suntarhyata no. 31, Scandinavia: 18 - Middalsbreen, 19 Blåisen (Norway), Alps: 20 - Morteratsch, 21 - Forni, Caucasus: 22 - Gergeti, Pamir Mountains: 23 - Lenin Glacier, Tien Shan: 24- Urumqi No.1, 25 - Grigoriev Ice Cap, 26 - Miaoergou, Quilian Shan: - 27 - Qiyi, Karakoram: 28 - Baltoro, Himalaya: 29 - Kang Yatse, 30 - Chamser Kangri, 31 - Yala, Kilimanjaro: 32 - Kersten, Andes: 33-Colombia (La Conojeras), 34 - Iver, 35 - El Morado, 36 - Exploradores, 37 - Tyndall, Maritime Antarctic: 38 - Marr Ice Piedmont, 39 - Blancmange, Continental Antarctic: 40 - Canada, 41 - Taylor, 42 Commonwealth. 
The presence of microinvertebrates was evaluated using two complementary approaches; a classical approach based on microscopy (dissecting, inverted or both) and environmental DNA (eDNA) metabarcoding. Sampled cryoconite holes varied in shape and size across regions, across glaciers, and across the same glacier (Fig. 2). For microscopy, we collected sediment samples from the bottom of each hole by two methods determined by whether the holes were open or frozen. Sediments from open holes were sampled with independent sterile disposable Pasteur pipettes or scoops and placed directly in vials, zipp bags or jars. Sediments from frozen holes were retrieved from a $10-\mathrm{cm}$-diameter core and placed into sterile plastic bags. All sediment samples were either immediately frozen or preserved in $70 \%$ or $96 \%$ ethylic alcohol, then transported to home laboratories at the Adam Mickiewicz University in Poznań (Poland); Cardiff University (UK); Chiba University (Japan); University of Colorado Boulder (USA); or Charles University and Biology Centre AS CR (Czech Republic). At least $0.3-1.5 \mathrm{~mL}$ (in few cases for samples from Longyearbreen, Hansbreen and Marr) up to $10 \mathrm{~mL}$ of preserved cryoconite material was scanned from each sample for the presence of invertebrates on Petri dishes scored with perpendicular lines (for facilitating observations). Frozen cores collected from glaciers located in McMurdo Dry Valleys were melted and subset as described below in the Crary Lab in McMurdo, Antarctica, where microinvertebrates were extracted from $20 \mathrm{~g}$ of melted sediment subsamples using modified White Trays for $24 \mathrm{~h}$ (Porazinska et al., 2018) and immediately counted.
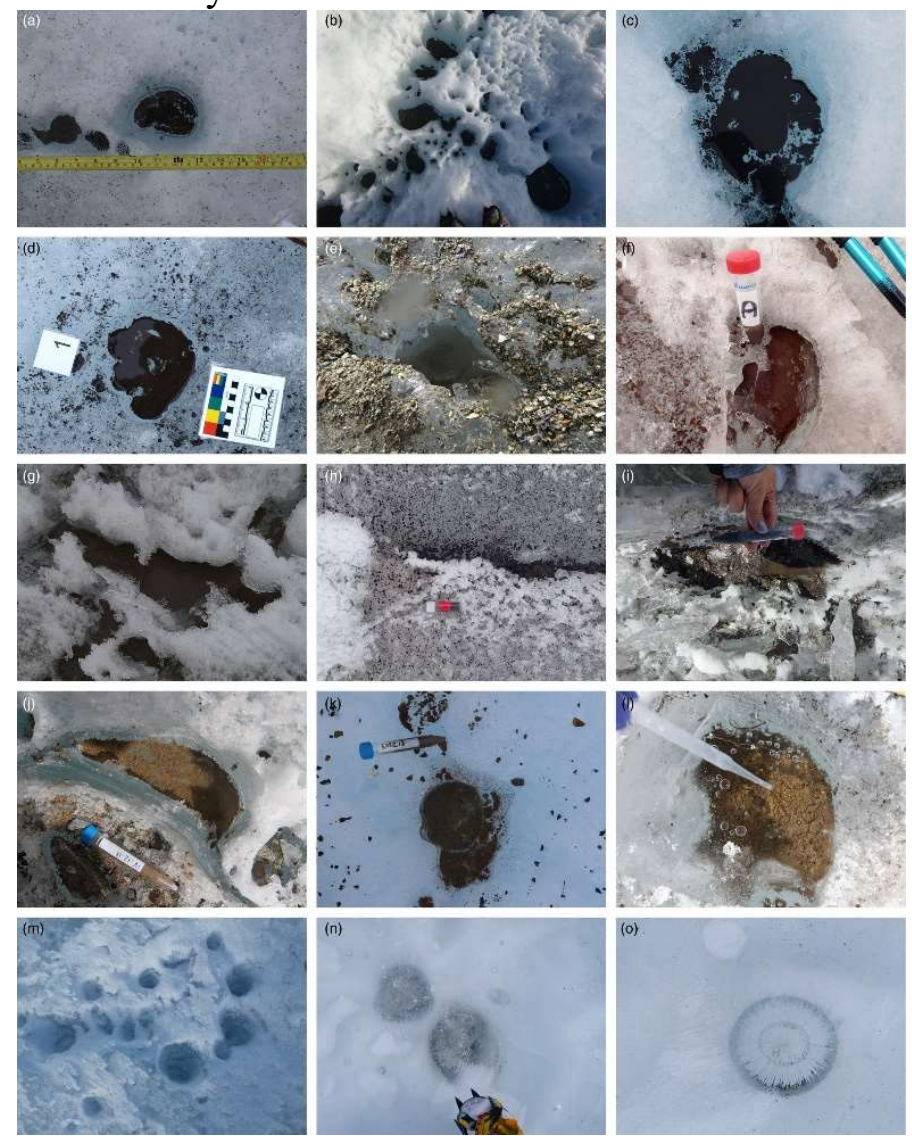

Figure 2. Cryoconite holes on glaciers around the world. (a) Svalbard, Longyearbreen, August 2016, (b) southwest Greenland, September 2015, (c) Norway, Blåisen, August 2018, photographs for all K. Zawierucha, (d) Alps, Forni, July 2017, photograph J. Buda, (e) Caucasus, Chaalati, July 2014, photograph K. Zawierucha (f) Caucasus, Gergeti, September 2019, photograph A. Kościński, (g) Himalaya, Kang Yatse, August 2017, photograph M. Devetter (h) Colombia, La Conejeras, 2015, photograph Jun Uetake, (i) Kilimanjaro, Kersten, September 2019, photograph U. Fuglewicz, (j) Andes, Iver, 2018, photograph R. Ambrosini, (k) Andes, Exploradores, 2018, photograph R. Ambrosini, (l) Maritime Antarctica, Ecology, January 2017, photograph T. Budzik, (m) Maritime Antarctica, Marr Ice Piedmont, February 2018, photograph I. Parnikoza, (n, o) Continental Antarctica, Canada, December 2017, photograph P. Sommers. 
In addition to microscopy counts, samples for eDNA metabarcoding analysis were collected from Forni Glacier in the Alps, Baltoro Glacier in the Pakistan Karakoram and McMurdo Dry Valleys glaciers in Antarctica (Taylor, Canada and Commonwealth glaciers). We performed metabarcoding analyses at two laboratories: University of Milan and University of Colorado.

For the University of Milan metabarcoding analysis, samples from Forni (18 samples on August 28th, and 19 samples on September 25th) and the Baltoro Glacier (19 samples from June 28th to July 9th) were collected in 2013. Cryoconite was deposited with a laboratory spoon (sterilized with alcohol) into $50 \mathrm{~mL}$ plastic tubes. Total DNA was extracted from $0.7 \mathrm{~g}$ of cryoconite using the FastDNA Spin for Soil kit (MP Biomedicals, Solon, OH, USA) according to the manufacturer's instructions. The extracted DNA was amplified in quadruplicates with the primers Euka02, which amplifies a 123 bp fragment of 18S rDNA (Guardiola et al., 2015; Taberlet, Bonin, Zinger, \& Coissac, 2018). The primer pair amplifies all eukaryotes at the family/order level (Guardiola et al., 2015; Taberlet et al., 2018). The amplification success was checked using Capillary electrophoresis (QIAxcel System; Qiagen, Venlo, Netherlands). Extraction and PCR controls were also included (Parducci et al., 2017). Sequencing was performed using Illumina MiSeq V2 platform $(2 \times 250 \mathrm{bp}$ chemistry $)$ at Fasteris, Geneva, Switzerland. DNA sequences were filtered (i.e. removing sequences: with low quality score; missing both primers or exact tag sequences; containing ambiguous nucleotides, shorter than 7 bp; or occurring only once in the dataset) and chimera-checked using the OBITOOLS software (Boyer et al., 2016). For the Forni + Baltoro metabarcoding experiment, 2.39 million reads were retained after the bioinformatic filtering steps and assigned to the samples (average number of reads per sample: 28 821). Potential contaminants - identified as those with highest occurrence in negative control samples - were removed. Sequences were retained in the final dataset only if their taxonomic assignment score was $>80 \%$ and their occurrence was higher than 100 reads across the whole dataset. Pansu et al. (2015) provide a complete description of the filtering steps. Sequences were assigned taxonomy using the ecotag program and EMBL database (Boyer et al., 2016).

For the University of Colorado metabarcoding analysis, 90 samples were collected from frozen cryoconite holes on three glaciers in the McMurdo Dry Valleys, Antarctica using a SIPRE corer between 7 and 17 November 2016. Sampling details are described in Darcy et al. (2018) and Sommers et al. (2019). The cores were stored in sterile Whirl-Pak ${ }^{\circledR}$ bags (Nasco, Fort Atkison, WI, USA) at $-20^{\circ} \mathrm{C}$ for up to 1 month. In the Crary Laboratory at McMurdo Station, the sediment portion was separated from the rest of the core and washed with deionized water to melt the outer layer and remove potential cross-contamination from the drill, then placed in separate acid-washed high-density polyethylene beakers covered with aluminium foil and melted at $4^{\circ} \mathrm{C}$ for $12-24 \mathrm{~h}$. Final melting took place at room temperature when necessary immediately prior to homogenizing, subsampling and filtering. DNA was extracted from c. 0.3 g cryoconite using a PowerSoil DNA Isolation Kit (MoBio Inc., Carlsbad, CA, USA). Tubes were frozen at $-20^{\circ} \mathrm{C}$ until the DNA was extracted, up to 1 month later, following the manufacturer's protocol. Extracted genomic DNA was amplified in triplicate using 18S (1391fEukBr primers, Amaral-Zettler, McCliment, Ducklow, \& Huse, 2009; Caporaso et al., 2012) SSU ribosomal gene markers. Amplified DNA was pooled and normalized to equimolar concentrations using SequalPrep Normalization Kit (Invitrogen Corp., Carlsbad, CA, USA) and sequenced using the Illumina MiSeq V2 $(2 \times 250$ bp chemistry $)$ at the BioFrontiers Sequencing Core Facility at the University of Colorado at Boulder. Sequences have been deposited in the NCBI SRA database under project PRJNA480849. At the Colorado laboratory, we used QIIME v1.9.1 (Caporaso et al., 2010) to de-multiplex and quality filter the raw reads, and VSEARCH (Rognes et al., 2016) to join paired-end reads. The reads were clustered into operational 
taxonomic units (OTUs) at 97\% similarity using UCLUST (Edgar, 2010). Taxonomy was assigned using QIIME's parallel_assign_taxonomy_blast.py script with a hand-curated version of SILVA 128 Ref NR99 database (Quast et al., 2013). Based on this classification, bacterial OTUs were removed from the eukaryotic OTU table. Singletons were discarded, as were any OTUs that made up at least $1 \%$ of the extraction blank sequences and were at least $1 \%$ of the samples, which were considered likely lab contaminants. A total of 2.36 million high-quality joined reads remained after this processing of reads from the 90 cryoconite hole samples, along with an additional 10 samples from stream microbial mats surrounding Canada Glacier in the Taylor Valley, Antarctica, included as a positive control for the presence of nematodes (see Supporting Information Figure S2).

Previously published distribution data

Published literature about cryoconite holes was identified using Scopus, Web of Science, Google Scholar and ResearchGate search engines with the following keywords: biota, cryoconite, cryoconite hole, ecosystems, glacier, glacial, animal, invertebrates, insects, Tardigrada, Rotifera, Nematoda, biodiversity and metazoans. All papers reporting microinvertebrate in cryoconite holes were included in the present study (Supporting Information Table S2), with an important exception. We excluded from our literature search studies based solely on metagenomic DNA analysis that report the presence of sequences matching Nematoda alongside sequences of organisms such as members of Chordata, marine Echinodermata and tropical Onychophora (e.g. Edwards et al., 2013). The reporting of these taxa that are certainly not part of the active cryoconite community makes it impossible without microscopic confirmation to know whether nematode sequences also originated from individuals living outside the cryoconite holes. Cases where microinvertebrates are known by the authors as present in samples but unreported in original papers are also listed in Supporting Information Table S2 (e.g. rotifers in Takeuchi \& Kohshima, 2004 and Zawierucha et al., 2016). As specific papers often focused a single taxon from cryoconite hole samples, omissions of other taxa from the paper were not taken as conclusive evidence of their absence from those samples. Although survey methods differed among studies (e.g. microscopy vs. molecular gene markers), we included publications from a variety of survey methods to better understand the biogeography of microinvertebrates in cryoconite holes.

\section{Results \\ Original data}

We investigated material from 42 glaciers globally (Figs 1 and 7, Supporting Information Table $\mathrm{S} 1)$. Using microscopy, we found that cryoconite holes were dominated mostly by tardigrades and rotifers (Figs 3, 4 and 7); unexpectedly, nematodes were never observed (Fig. 7). We found considerable differences among glaciers in taxonomic dominance. In the Arctic (Svalbard, Greenland) and Continental Antarctic, cryoconite holes were co-dominated by tardigrades and rotifers regardless of glacier thermal regimes or type (polythermal, cold base, valley, tidewater), or latitude or altitude in Svalbard and south-west Greenland. Cryoconite holes on Norway's Blåisen were dominated by rotifers, although a few tardigrades were also present in both 2018 and 2019. Cryoconite holes on Forni in the Alps during 2019 showed the opposite pattern with nearly exclusive presence of tardigrades and only a few rotifers. Dominance of tardigrades was similarly observed on Gulkana on Alaska sampled in 2015 and 2019. In contrast, cryoconite holes on the Alpine Morteratsch in 2017 and 2018 supported neither tardigrades nor rotifers. Similarly, cryoconite material from Gergeti in the Caucasus, Suntarhyata no. 31 in Siberia, Storglaciären in Sweden and Marr in the Maritime Antarctic, all appeared to be free of any animals in cryoconite holes. Out of five sampled glaciers in Colombia and Chile, rotifers were 
found on only two (La Conejeras and Tyndall), whereas no tardigrades have been reported in South America. No tardigrades, but many rotifers, were also detected from Kersten in Tanzania and Ecology on King George Island (South Shetland Islands).
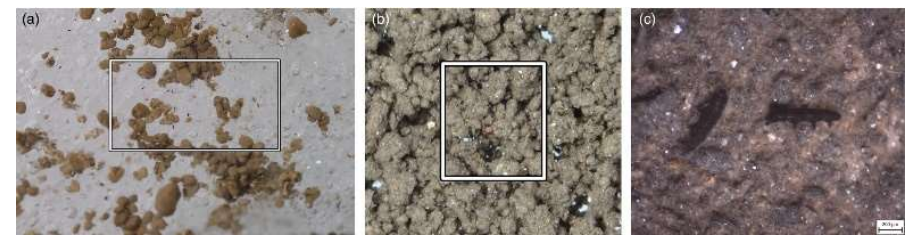

Figure 3. Tardigrada. (a) Cryoconicus kaczmareki Zawierucha et al., 2018 from Ürümqi Glacier (Central Asia) - dark small dots in the frame, and (b, c) Cryobiotus klebelsbergi (Mihelčič, 1959) from Forni Glacier (picture b - small brownish dots on cryoconite granules in the frame).

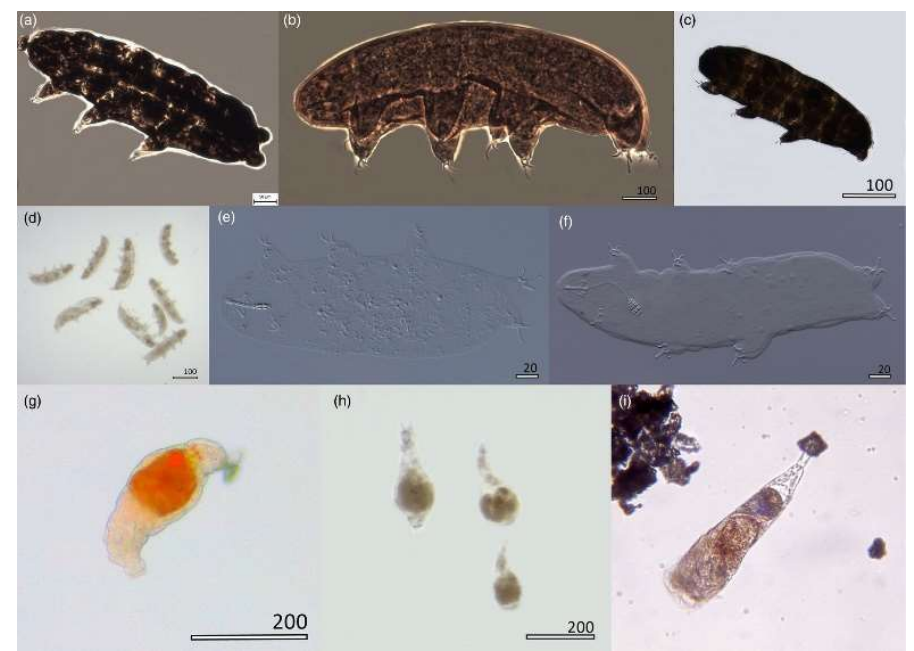

Figure 4. Tardigrada (a-f) and Rotifera (g-i). (a) Cryobiotus klebelsbergi (PCM - phase contrast microscopy), (b) Cryoconicus kaczmareki (PCM), (c) eutardigrade from Gulkana glacier (DIC - differential interference contrast microscopy), (d) tardigrades from Svalbard (Longyearbreen) BFM - (bright-field microscopy), (e) Hypsibius cf. dujardini from Svalbard (DIC), (f) Pilatobius sp. from Greenland (DIC), (g) bdelloid rotifer from Svalbard, (h) bdelloid rotifers from Greenland (preserved in alcohol) and (i) bdelloid rotifer from Tyndall Glacier (BFM - g, h, i).

Out of the 480 molecular operational taxonomic units (OTUs) recovered from eDNA analysis on Forni and Baltoro samples, the majority were assigned to protists (36\%) and fungi $(31 \%)$ (Fig. 5, Supporting Information Figure S3, Supporting Information Table S3). Almost two per cent $(1.8 \%)$ of MOTUs belonged to metazoan taxa from three phyla: Arthropoda, Rotifera and Tardigrada (Supporting Information Table S3). None of the detected MOTUs were assigned to Nematoda. Comparison of sequences belonging to invertebrates from Forni, Baltoro and Continental Antarctic glaciers shows a clear dominance of tardigrades on Forni and Baltoro (with minority of arthropods and rotifers) and coexistence of rotifers and tardigrades (with dominance of the former) on Antarctic glaciers (Fig. 5). 


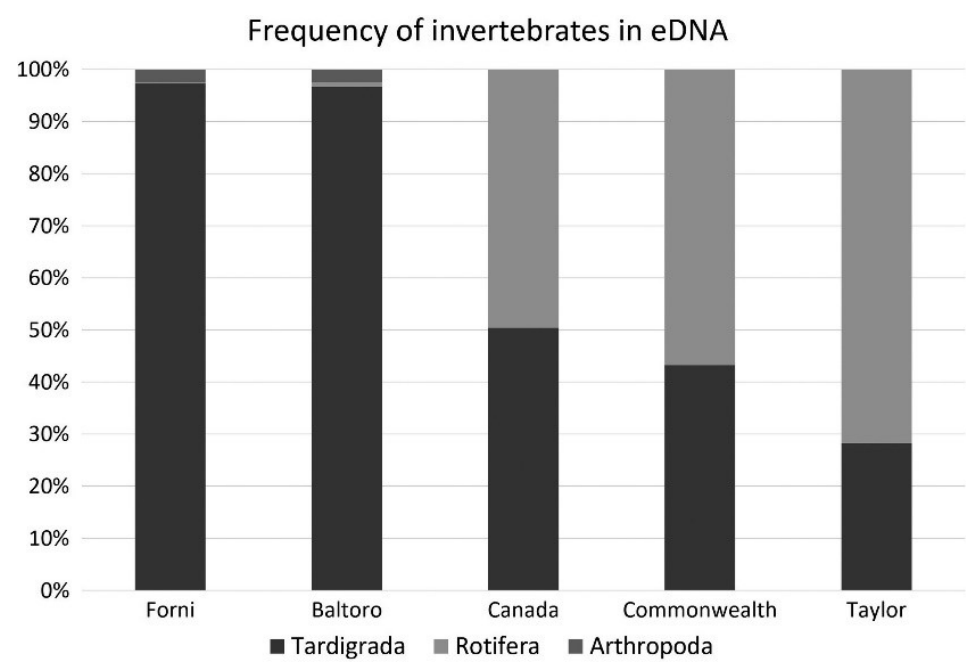

Figure 5. Frequencies of invertebrate sequences detected in eDNA using fragment of 18S rDNA from cryoconite holes on Forni (Alps), Baltoro (Karakoram) and Antarctic glaciers (Canada, Commonwealth and Taylor).

\section{Previously published distribution data}

Our review of 46 publications in which 41 localities (Supporting Information Figure S1, Supporting Information Table S2) were investigated, confirmed that cryoconite holes around the world are mostly inhabited by either tardigrades, rotifers or both (Supporting Information Table S2). In some cases, cryoconite holes are inhabited by other animal groups such as Diptera in New Zealand (Odell, 1956; Boothroyd \& Cranston, 1999) and the eastern Himalaya, Gangla Karchung La (R. Dial, pers. obs.), Plecoptera in the Andes, Copepoda in the Himalaya, or Acari in the Maritime Antarctica (Buda et al., 2020) (Fig. 6). However, these animals have narrow geographical distributions and mostly represent endemic species (Kohshima, 1984, 1985). Some studies focused on the description or redescription of new microinvertebrate taxa (Mihelčič, 1959; Ramazzotti, 1968; Dastych, 1993, 2004, 2019; Kikuchi, 1994; Dastych, Kraus, \& Thaler, 2003; Zawierucha et al., 2018b). Others aimed to describe cryoconite communities, and authors discussed all invertebrates found in cryoconite holes (De Smet \& Van Rompu, 1994; Grongaard et al., 1999; Porazinska et al., 2004; Vonnahme et al., 2016; Zawierucha et al., 2018a; Lutz et al., 2019; Zawierucha et al., 2019a, 2019b, 2019c; Buda et al., 2020). In some papers, animals were mentioned as an ecological variable; in others, the focus was on faunistic reports (Dastych, 1985; Dabert et al., 2015; Łokas et al., 2016). 

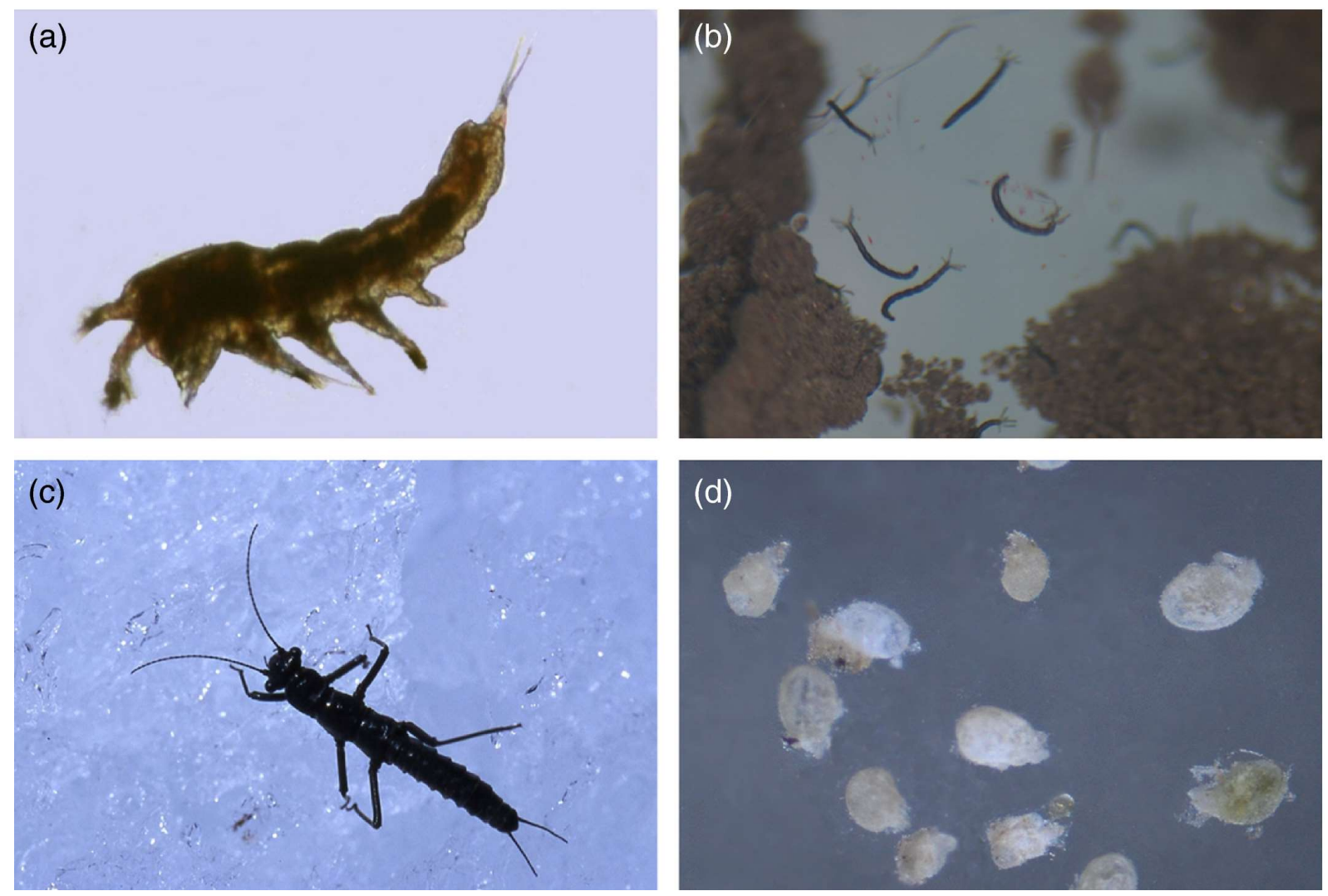

Figure 6. Arthropods found in cryoconite holes: (a) Copepoda in Himalaya (Kikuchi, 1994), (b) Chironomidae in Himalaya (Kohshima, 1984), (c) Plecoptera in Patagonia (Takeuchi \& Kohshima, 2004) and (d) Acari in the Maritime Antarctica (Buda et al., 2020).

Both old (Drygalski, 1897; Dastych, 1985; De Smet \& Van Rompu, 1994) and recent literature (Zawierucha et al., 2018a; Zawierucha et al., 2019a, 2019b, 2019c) indicate that Arctic cryoconite holes are inhabited by tardigrades and rotifers without any visible general pattern at the global scale (Supporting Information Figure S1, Supporting Information Table S2). In the Alps, Zawierucha et al. (2019a) and Dastych et al. (2003) found cryoconite holes inhabited by tardigrades with only little or no rotifer presence, over multiple summers. However, tardigrades and rotifers were found earlier by Steinböck (1936) on other glaciers in the Alps (albeit without quantitative data). Analysis of material from Chalaati and Adishi glaciers in the Caucasus showed that neither tardigrades nor rotifers were present (Makowska et al., 2016). The literature suggests that Central Asian glaciers are inhabited mostly by tardigrades; however, some of papers from this area were purely taxonomic (Supporting Information Table S2) and offered no descriptions of entire invertebrate assemblages.

In the Maritime Antarctica, cryoconite holes on the Ecology Glacier (King George Island, South Shetland Islands) were inhabited by rotifers, but no tardigrades nor nematodes were found (Zawierucha et al., 2019b). Microscopy-based and eDNA surveys of cryoconite holes on Continental Antarctic glaciers showed the presence of both tardigrades and rotifers (Porazinska et al., 2004; Sommers et al., 2018; Lutz et al., 2019). Porazinska et al. (2004) sampled five Dry Valley glaciers and found relatively equitable rotifer:tardigrade ratios in the wetter east but very high rotifer:tardigrade ratios in the drier west. Both groups were least abundant on the glaciers receiving the least snow. In cryoconite holes in Marie Byrd Land, Continental Antarctica, only rotifers were reported (Broady, 1989), whereas in cryoconite holes in Queen Maud Land both rotifer and tardigrade DNA were found together three times and separately five times (tardigrades once, rotifers four times) in ice covered cryoconite holes (Lutz et al., 2019). Of the 
5014 97\% similarity OTUs recovered from the cryoconite hole sediments in Continental Antarctica (Canada, Taylor, and Commonwealth glaciers), 14\% were assigned to Rotifera and Tardigrada, and these OTUs accounted for $30-40 \%$ of the reads in the samples (Sommers et al., 2019). Two studies from Antarctica detected nematodes in cryoconite holes. One used classical microscopy (Mueller, Vincent, Pollard, \& Fristen, 2001), while the other used eDNA analysis (Christner et al., 2003). Other studies from the same glaciers reported no nematodes in cryoconite holes (Porazinska et al., 2004; Sommers et al., 2019). While Sommers et al. (2018) reported the presence of nematode sequences using eDNA, these samples did not have microscopy associated with them and later, more extensive sampling of cryoconite holes from the same glaciers including microscopy (Sommers et al., 2019) failed to find nematodes (Fig. 7). Also Murakami et al. (2018) detected nematodes in the faecal metagenomes of Plecoptera Andiperla willinki which also might be found in cryoconite holes. However, the presence of nematodes in faeces does not offer conclusive evidence of their presence in cryoconite holes because Plecoptera could find their preys directly on the glacier surface.

Invertebrate groups detected in cryoconite holes

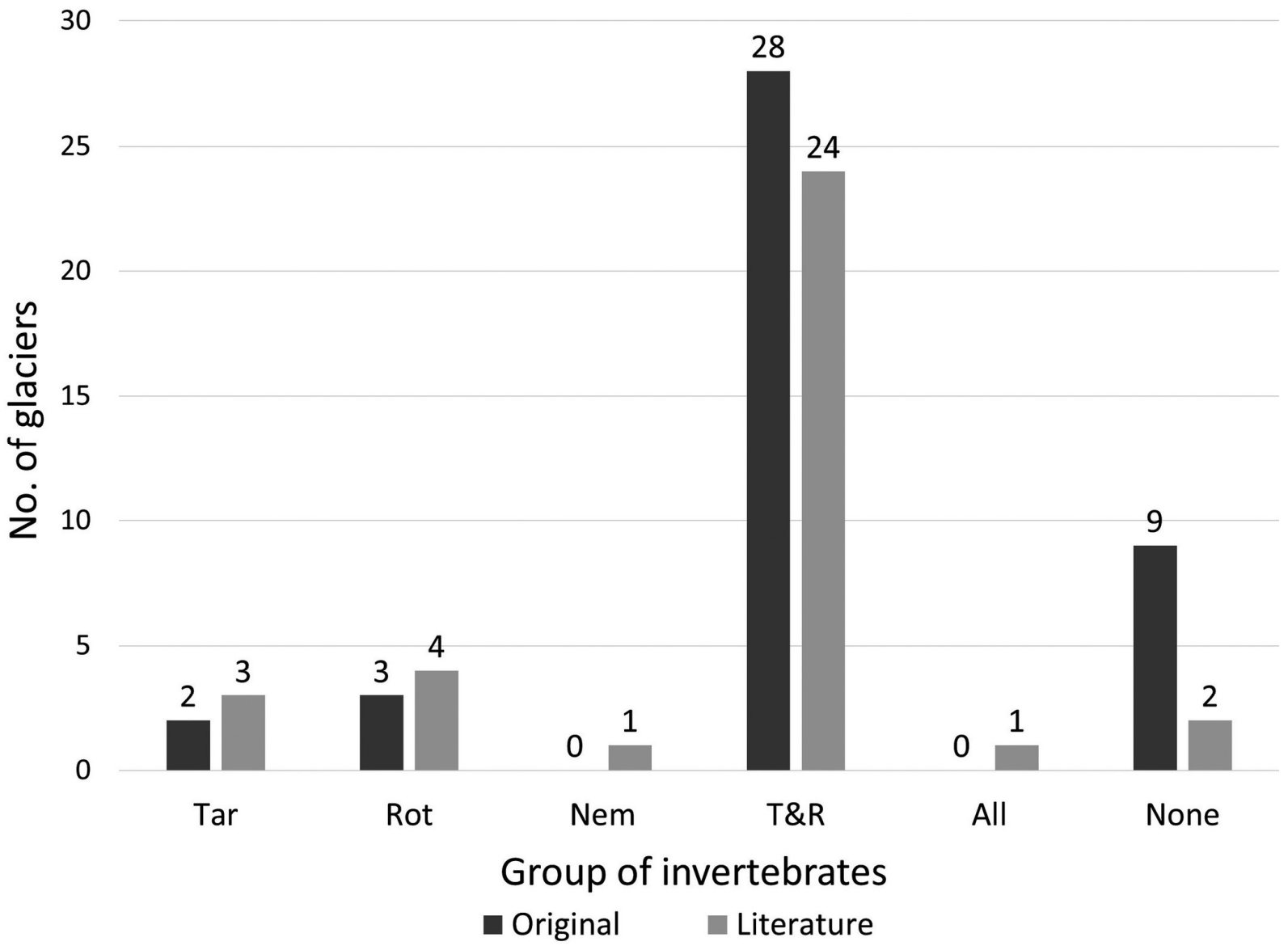

Figure 7. Invertebrate groups (Tardigrada, Rotifera, Nematoda) detected in cryoconite holes on glaciers (original and literature data, Fig. 1, Supporting Information Figure S1, Supporting Information Tables S1 and S2). T\&R: Tardigrada and Rotifera; Tar: Tardigrada; Rot: Rotifera; Nem: Nematoda; All: all three (Tardigrada, Rotifera and Nematoda); and None: absence of these groups from cryoconite holes of studied glaciers. In literature data, taxonomic papers focused only on particular groups were removed from this comparison. For selection criteria of literature records, see Supporting Information Table S1. In consulting original data, we considered dominance by a group when cryoconite was exclusively dominated by one group with few or no coexisting specimens of another. 


\section{Discussion \\ Dominant taxa}

In this study, we used both original data (Fig. 1, Supporting Information Table S1) and published records (Supporting Information Figure S1, Supporting Information Table S2) to show that the microinvertebrate communities in cryoconite holes from $>70$ locations consist of mostly rotifers, tardigrades or both, but, with the exception of two studies in Antarctica (one microscopy-based and one genetic), never include nematodes. Although nematodes have been detected in glacial mosses (Coulson \& Midgley, 2012), on the glacial ice (D. Shain pers. obs.), in sediments overlying glacial surface (Azzoni et al., 2015; D. Porazinska pers. obs.), in sediments of glacial streams in Antarctica (P. Sommers \& D. Porazinska pers. obs.) or even in glacial Plecoptera faeces (Murakami et al., 2018), cryoconite hole environments seem not to provide the necessary conditions for growth and reproduction of nematodes.

Due to their physiological adaptations to survive low temperatures, freezing, high UV and osmotic stress (Altiero et al., 2011; Guidetti et al., 2012; Jönsson \& Wojcik, 2017; Zawierucha et al., 2018b; Zawierucha et al., 2019a), dominance in cryoconite holes by tardigrades and rotifers is not surprising. Despite the similarity of conditions across cryoconite holes (e.g. low temperatures, periodic freezing), the composition of animal phyla varied within regions and even within glaciers. On Blåisen (Norway), Forni (the Alps), Ecology (Maritime Antarctic) and Kersten (Africa) glaciers, cryoconite holes were dominated by either rotifers or tardigrades. For example, in Norway (Blåisen, Midtdalsbreen), we observed the numerical dominance of rotifers over tardigrades. Regrettably, detailed records of the cryoconite hole community structure on the same glaciers in previous studies were missing; consequently, it was impossible to infer which group dominated in the past (Sømme, 1996). In the Alps, on Forni Glacier, there was almost excusive dominance by tardigrades over multiple seasons (Zawierucha et al., 2019a, present study). The same pattern was observed on Rotmoosferner in the Alps by Dastych et al. (2003), who reported few rotifers among thousands of tardigrades in cryoconite material. Arctic and Continental Antarctic cryoconite holes hosted both rotifers and tardigrades, while no invertebrates were detected in cryoconite holes on Morteratsch Glacier in the Alps (sampled during two seasons) or on Adishi, Chalaati and Gergeti glaciers in the Caucasus. Tardigrades were undetected in cryoconite holes in South America, whereas rotifers were found on one Colombian and one Chilean glacier. Taking into account the high dispersal abilities of both terrestrial and glacier invertebrates (Jørgensen, Møbjerg, \& Kristensen, 2007; Ptatscheck, Gansfort, \& Traunspurger, 2018; Zawierucha et al., 2018b; Fontaneto, 2019; Zawierucha et al., 2019a), we hypothesize that the nature of glaciers (thermal regime, type, altitude, latitude) is not the driving factor of microinvertebrates distribution patterns. Instead, local climatic or environmental factors and infrequent extreme weather events (e.g. strong rains (Zawierucha et al., 2019c)) might be more important. More intense and standardized (using the same techniques and combining molecular and microscopy approaches) sampling, long-term monitoring and manipulative field experiments could resolve these questions.

\section{Other animals in cryoconite holes}

Zawierucha et al. (2015) postulated that cryoconite holes should be inhabited by many groups of micrometazoans, including crustaceans and gastrotrichs, as found in other polar or highalpine freshwater bodies (Janiec, 1996; Hinden et al., 2005; Kolicka et al., 2016). The habitat provides abundant organic matter as a food source and relatively low levels of competition. However, our global survey did not corroborate this hypothesis. We found evidence of only a few other animals being found in some cryoconite holes. The Northern and Southern Patagonian Icefields were inhabited by arthropods such as Plecoptera Andiperla willinki (Aubert, 1956) and Collembola. In addition, some Himalayan cryoconite holes were inhabited by copepods 
(Copepoda) and chironomids (Insecta) (Kohshima, 1984, 1985; Takeuchi et al., 2000; Dial pers. obs.). All of these examples are mostly endemic glacier-obligate invertebrates, which feed and reproduce in very narrow geographical areas (one mountain range, ice field or glacier). Recently, Zawierucha et al. (2019b) and Buda et al. (2020) reported presence of various instars of mite (Nanorchestes nivalis) in cryoconite holes on Ecology Glacier in the Maritime Antarctic during two seasons and showed that the mites on this glacier can be persistent residents of the cryoconite holes. Platyhelminthes have been reported by DNA in Continental Antarctica (Sommers et al., 2018); however, confirmation of their affinity with cryoconite holes requires microscopic analysis. Glacier ice worms (Mesenchytraues solifugus) - the only known glacierobligate annelid, were reported in cryoconite holes in the Pacific Northwest of North America (Goodman, 1971); however, despite the habitat suitability formed by stable thermal structure of cryoconite microenvironments (e.g. Gulkana Glacier), they were absent from the material analysed in this study. Collembola have been found in the bottom of cryoconite holes in the Alps and the Caucasus (Supporting Information Table S2), but benthic ecosystems are not their typical habitat and they have probably been passively dispersed to the holes by water, as observed in the Alps by Zawierucha et al., 2019a (Fig. 8, Supporting Information Figure S4). Springtails have also been reported in weathering crust on glaciers but not in the holes bottom (Fjellberg, 2010).
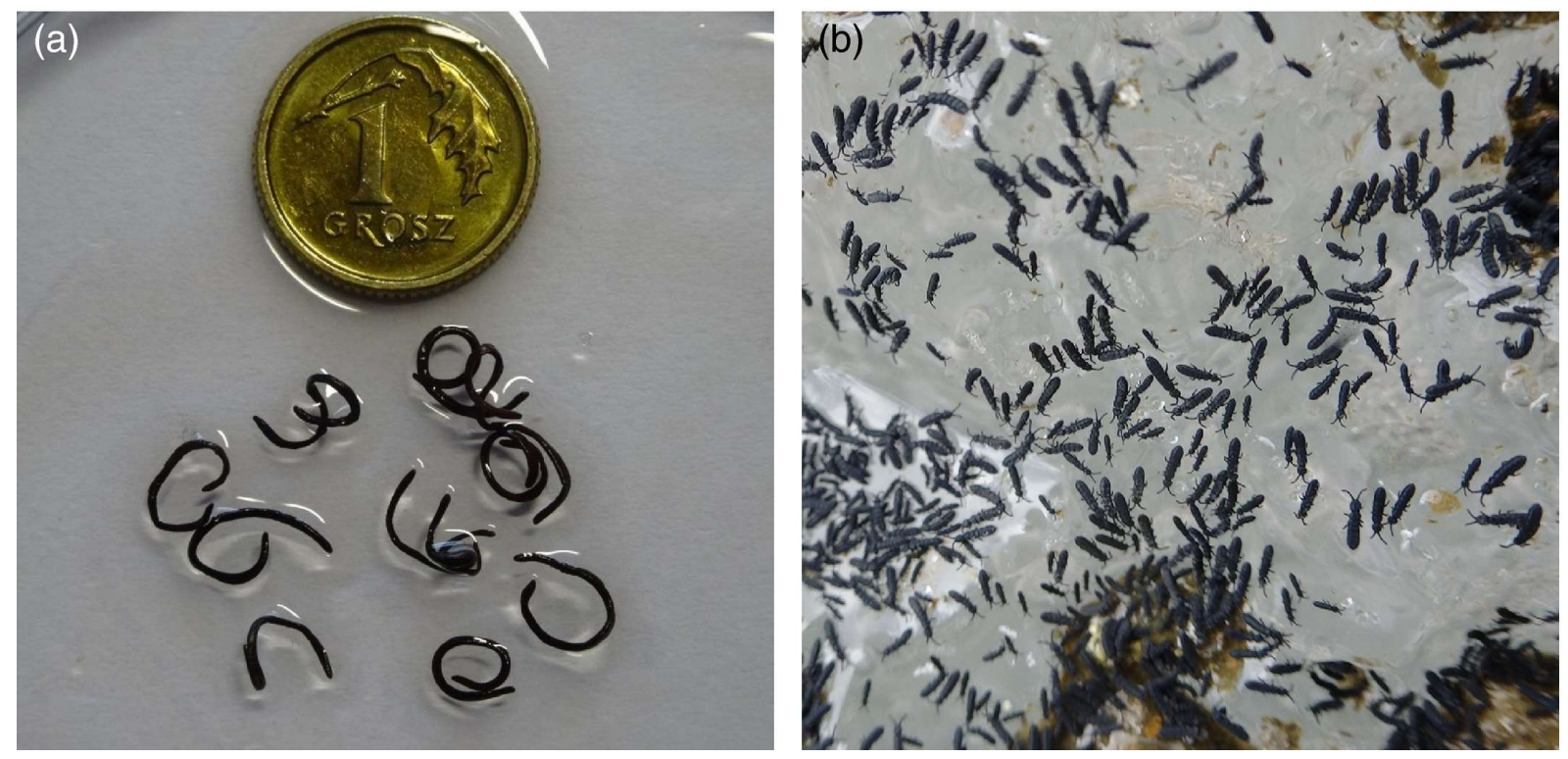

Figure 8. Animals known from glaciers that are occasionally found in cryoconite holes, yet inhabit other glacier niches: (a) Annelida (glacier ice worms, Mesenchytraeus solifugus) from an Alaskan glacier and known to be abundant in the englacial zone of the maritime glaciers. Polish grosz as a scale. (b) Collembola from a glacier in the Alps and known to be widespread and abundant on ice and snow surfaces, particularly under stones and in weathering crust (Fjellberg, 2010; Zawierucha et al., 2019a).

Although arthropods sequences were detected in environmental DNA, their absence (complete or active specimens) from microscope observations suggests the detected DNA sequences were likely due to wind-blown material rather than active components of communities on Baltoro and Forni glaciers. In samples from Forni and Baltoro glaciers, remains of insects (wings, legs, heads), but not living individuals, suggest insects are primarily allochthonous (confirmed in this study and Zawierucha et al., 2019a). Recently, Dastych (2019) found along with tardigrades 
and rotifers, several small fragments of arthropod cuticles, a dead small aphid and a beetle of the genus Bembidion in cryoconite holes on the Gihccejiekna Glacier in northern Norway. All of those arthropods were not typical cryoconite hole dwelling invertebrates but accidental faunal elements. Although Edwards et al. (2013) reported DNA sequences from many animal taxa from cryoconite holes in the Alps including marine Echinodermata, and tropical Onychophora, without a confirmation with microscopy the actual presence of live individuals which belongs to these groups is seriously doubtful. The disparity in richness of animals between cryoconite holes and other freshwater environments remains poorly understood and is one of the most striking scientific questions in studies on the distribution of invertebrates in the cryosphere.

Cryoconite holes as suitable habitats for cryophilic invertebrates

In some respects, cryoconite holes are not as extreme as often described (Maccario et al., 2015). Liquid water makes them oases of life in a frozen landscape, supporting abundant and diverse microbial communities and potentially providing sufficient food resources (Stibal et al., 2010; Cook et al., 2016; Zawierucha et al., 2018a; Buda et al., 2020). Even though cryoconite holes are harsh environments in many respects, they provide an adequate food resources for various invertebrates. Cryoconite holes are considered biodiversity hotspots for cryophilic species of algae, cyanobacteria, heterotrophic bacteria, amoebas, fungi and ciliates (Takeuchi, 2002; Hodson et al., 2008; Cook et al., 2016; Pittino et al., 2018; Sommers et al., 2018, 2019; Zawierucha et al., 2018a; Buda et al., 2020; Stibal et al., 2020). The biodiversity of photoautotrophs includes many opportunistic and glacier specific taxa which may attain the biomass of $0.998 \mu \mathrm{g} \mathrm{dm}-3$ and the photosynthetic rates from $0.63 \mathrm{C} \mathrm{L}-1 \mathrm{~h}-1$ to $156.99 \mu \mathrm{g} \mathrm{C}$ L-1 h-1 (Säwström et al., 2002; Buda et al., 2020). Metagenomic studies showed that copy number of $16 \mathrm{~S}$ rRNA gene (a proxy for bacterial concentration) ranges between regions, but is generally very high (105-107 copies g-1 on Adishi in the Caucasus, 108-109 copies g-1 on the Greenland ice sheet (Makowska et al., 2016, Stibal et al., 2015)). Cryoconite holes generate and store organic matter on glaciers (Stibal et al., 2010), for example up to 18\% in Greenland (Gerdel \& Drouet, 1960), 16\% in the Caucasus (Łokas et al., 2018), 14\% in Svalbard (Lokas et al., 2016), 13\% in Central Asia (Takeuchi, 2002) and 7\% in Maritime Antarctic (Buda et al., 2020). Moreover, apart from autochthonous production, cryoconite holes food webs on a small glacier receive allochthonous wind-blown organic input from fragments of mosses, leaves, insects and others windborne materials (Stibal \& Tranter, 2007; Dastych, 2019; Zawierucha et al., 2019a). Primary production in holes is comparable to other oligotrophic water pools in Arctic regions (Säwström et al., 2002; Michelutti et al., 2005), and the bacterial number is similar to other freshwater ecosystems (Bomberg et al., 2019). Values of organic matter in cryoconite holes surpass the organic matter content in oligotrophic lakes (c. 10\% in stonybottom lakes) that support diverse meiofaunal groups (Peters \& Traunspurger, 2005). Tardigrades in cryoconite holes are mostly herbivores and microbivores, while rotifers are filter feeders. Thus, microbivorous and omnivorous (even carnivorous) nematodes should find adequate resources for growth and reproduction. However, it is possible that specific food sources required by invertebrates such as nematodes are missing from these environments. As cryoconite holes are the most productive and species-rich habitats on glacial surfaces, more factors than only trophic resources must prevent nematodes from occupying this aquatic habitat. More holistic and thorough approaches to studying cryoconite communities are therefore necessary to describe their ecological networks and limiting factors.

\section{Limiting factors}

This study spanned a worldwide collection of glaciers from a broad variety of environmental conditions, from cold-polar, to wet-temperate, to dry, high-altitude glaciers. We therefore 
suggest that factors other than biogeographical region, climate, latitude and light cycles explain the presence of tardigrades and rotifers and the absence of nematodes in cryoconite holes.

The harsh physical conditions of glacial environments may reduce the faunal diversity in cryoconite holes. Surrounded by ice instead of soil and rock, cryoconite holes remain near freezing even during summer days and freeze solid over winter. For instance, the temperature in cryoconite holes on Arctic glaciers in summer averages $0.08^{\circ} \mathrm{C}$ with a maximum of $0.22^{\circ} \mathrm{C}$, (Zawierucha et al., 2019c). In comparison, shallow polar ponds or lakes may reach $10^{\circ} \mathrm{C}$ (Sheath, 1986; Schneider et al., 2016) and consequently can be inhabited, not only by tardigrades and rotifers, but by a diversity of freshwater fauna (Coulson et al., 2014; Kolicka et al., 2016). The permanently low temperatures in cryoconite holes may suppress basic life activities, including reproduction, hatching and foraging.

In addition to low temperatures, cryoconite holes are dynamic environments and characterized by periodic freezing, removal of sediments from the bottom, ablation and/or collapse during extreme weather events (e.g. rain and föhn winds) (Mueller et al., 2001; Fountain et al., 2004; Zawierucha et al., 2019c). Consequently, animals can be exposed to intense UV radiation directly on the surface or simply be flushed out into the proglacial field. Most importantly, not even all tardigrades are able to enter anhydrobiosis (Bertolani et al., 2004; Nelson, Bartels, \& Guil, 2018), which might be a crucial mechanism to survival on the ice surface during the drying of removed sediment (Zawierucha et al., 2019a). Even though cryoconite tardigrades are able to survive desiccation, their recovery success is lower in comparison with other limno-terrestrial species (e.g. Bertolani et al., 2004; Schill \& Hengherr, 2019). Nevertheless, their anhydrobiotic state may favour dispersal (Zawierucha et al., 2019a). Indeed, desiccation enables their passive dispersal by wind (Nkem et al., 2006b) and successful colonization of new habitats on other glaciers. In contrast, limited anhydrobiosis may lead to endemism. For example, Himalayan copepods and chironomids, and New Zealand chironomids, Patagonian Plecoptera (Odell, 1956; Takeuchi et al., 2000; Takeuchi \& Kohshima, 2004; Murakami et al., 2018) are restricted to mountain glaciers in relatively small areas. Larger body size and a lack of anhydrobiosis abilities probably limit other microinvertebrates in terms of passive aerial dispersal and successful establishment on glaciers, specifically in cryoconite holes.

The low concentration of available phosphorous or nitrogen in water to support primary producer populations could furthermore limit the diversity of invertebrates in cryoconite holes. Such a hypothesis related to freshwater ecosystems was previously suggested by Hart \& Robinson (1990) and demonstrated in experimental freshwater mesocosms (Urabe, Clasen, \& Sterner, 1997; Michiels \& Traunspurger, 2005). The negative influence of phosphorous limitation on zooplankton and benthic grazers is well known in freshwater systems (Hart \& Robinson, 1990; Urabe et al., 1997). Glaciers are very likely ecosystems where organisms are limited by dissolved phosphorous availability (Holland et al., 2019), which is a crucial biogenic element. This, in turn, may limit the presence of other taxa in cryoconite holes, but to our knowledge nematodes are not more sensitive to the resulting effects on the food web of phosphorous limitation than are other microinvertebrates.

Anthropogenic contaminants might constitute another factor potentially reducing animal diversity, albeit perhaps a minor role (Lorimore et al., 1998; Bezchlebová et al., 2007; Hussain et al., 2009). Worldwide, contamination of supraglacial ecosystems by pollutants includes black carbon, POPs (persistent organic pollutants), radionuclides and heavy metals (Hodson, 2014; Baccolo et al., 2017; Ferrario et al., 2017; Łokas et al., 2018). For example, on Adishi Glacier in the Caucasus, unexpected high concentrations of radionuclides have been detected, and a 
concomitant absence of animals (except for few collembolans) has been observed (Lokas et al., 2018). A similar observation was made on Morteratsch in the Alps (Baccolo et al., 2017). However, radionuclide contamination has only been investigated for one glacier in the Caucasus and a few in the Alps, suggesting that this topic deserves further investigation. Moreover, in Continental Antarctica, contamination of the cryosphere is low (Khan et al., 2017), but nematodes are absent from cryoconite holes there as well. Thus, contaminants alone cannot explain nematode absence.

\section{Absence of nematodes}

Generally, tardigrades, rotifers and nematodes all enjoy large geographical ranges across a multitude of habitats. The three phyla often coexist in both terrestrial and aquatic (freshwater and marine) ecosystems (Schwarz et al., 1993; Janiec, 1996; Albuquerque et al., 2007). Nematodes are considered one of the most hyperdiverse taxa on Earth and the most abundant multicellular organisms (Hodda, 2007; van den Hoogen et al., 2019). Besides taxonomic diversity, they also present a variety of feeding habits, including algal, bacterial and fungal feeders, omnivores, predators and parasites. Although many species are well adapted to survive desiccation, they are aquatic organisms needing at least a film of water for movement, feeding, growth and reproduction to occur (Wharton, 1986). Consequently, cryoconite holes, due to the presence of liquid water and potential food sources, appear to be suitable habitats for nematodes.

Though nematodes are one of the most resilient invertebrate groups, able to survive under many unfavourable conditions (Treonis, 2005; Nkem et al., 2006a, 2006b; Hodda, 2007; Wharton \& Raymond, 2015), it seems odd that the conditions of cryoconite holes appear unsuitable for their growth. Since nematodes were absent from all the cryoconite holes we investigated, we suspect that evidence of nematodes in cryoconite by Mueller et al. (2001), Christner et al. (2003) and Sommers et al. (2018) may be allochthonous. In support of this interpretation, Nkem et al. (2006b) reported mostly dead nematodes in air traps on Antarctic glaciers. Similarly, sediments on the surface of Antarctic glaciers often support abundant populations of bacterial-feeding nematode Plectus sp. (D. Porazinska, pers. obs.), but never inside cryoconite holes. Christner et al. (2003) used a small subset of samples from Porazinska et al. (2004), where a large amount of sediments were processed for counts without detecting a single nematode. Similarly, nematode DNA presence reported by Sommers et al. (2018) was not supported by microscope counts from subsequently collected samples from the same glaciers.

Even though nematodes are well adapted to tolerate cold in terrestrial habitats, permanently low temperatures in cryoconite holes may limit their reproduction or limit their ability to compete for food with rotifers and tardigrades. For instance, nematodes survive freezing and desiccation in Antarctic soils through dormancy but reproduce when water and temperature conditions are favourable (Wharton, 2003). The presence of nematodes overlying glaciers in supraglacial debris (Azzoni et al., 2015) and in glacier mice (Coulson \& Midgley, 2012) indicates the presence of these favourable conditions in these habitats. Overhoff, Freckman \& Virginia (1993) found that temperatures of $10^{\circ} \mathrm{C}$ were required for growth of Scottnema lindsayae, the most dominant Antarctic nematodes adapted to cold soils - a temperature unlikely achieved in ice-bound cryoconite holes. This hypothesis is corroborated by previous observations of Zawierucha et al. (2019a) who did not find nematodes in cryoconite holes on Forni Glacier, but did find them in sediments from a proglacial lake. Similarly high Arctic tundra tardigrades (different than Arctic cryoconite hole species (K. Zawierucha et al., under review)) reproduce faster in higher temperatures (D. Stec pers. comm.). It could be that - as with the North American ice worm, an obligate glacier-dwelling organism that can not survive below about 
$-7^{\circ} \mathrm{C}$ (Dial et al., 2016) - the flexible cuticle of a vermiform morphology cannot survive the cold damage of being immersed in nearly pure frozen water, something that tardigrades and rotifers in cryoconite holes can withstand. This hypothesis would seem amenable to experimentation.

As nematodes are among the most numerous benthic animals in oligotrophic lakes (Ristau \& Traunspurger, 2011; Majdi \& Traunspurger, 2015), low levels of nutrients do not appear to determine their presence/absence. To explain the absence of nematodes from the otherwise apparently suitable habitat offered by cryoconite holes, we hypothesize the existence of some other biological or ecological barriers. Cyanobacteria are reported to be inhibitory towards some nematode species: for example, in permanent cyanobacteria mats or blooms in freshwater ecosystems (Muñoz et al., 2006; Nascimento et al., 2009). However, this hypothesis fails for some environments, as demonstrated by Jungblut, Vincent \& Lovejoy (2012) who showed that nematodes are found in Arctic and Antarctic cyanobacterial mats (see also Supporting Information Figure S2). Another barrier may be rapid changes in oxygen. While cryoconite holes are considered ultraoligotrophic environments, rapid development of anoxic zones in the sediment has been observed by Poniecka et al. (2018). Quick shifts from oxic to anoxic conditions may be a potential barrier for survival and reproduction, enabling the existence of only some taxa that can respond equally rapidly. Finally, microbial assemblages in cryoconite holes are distinct from those in soil or benthic environments (e.g. Franzetti et al., 2017), such that crucial components of the nematode diet are missing. Thus, competition and absence of necessary resources may prevent nematode occupancy of cryoconite holes. Undoubtedly, further studies will be necessary to confirm the absence of nematodes from cryoconite holes and other englacial and subglacial habitats characterized by temperatures that are almost constantly near-freezing. Subglacial ecosystems, considered for years by the scientific community to be sterile, have now gained scientific attention by biologists and bio-geochemists, with many studies currently addressing their diversity and productivity (Yde et al., 2011; Achberger et al., 2017; Dubnick et al., 2017; Zdanowski et al., 2017). We cannot exclude the hypothesis that some specialized nematodes inhabit both subglacial ecosystems and englacial channels thermally similar to cryoconite holes. For example, Northern American glaciers host oligochaetes inhabiting the englacial zone (Dial et al., 2012; Dial et al., 2016). Similarly, deeper layers of weathering crust are inhabited by rotifers on Icelandic glaciers (Shain et al., 2016) and also nematodes on New Zealand (D. Shain pers. obs.).

\section{Conclusion}

The microinvertebrate communities of cryoconite holes worldwide appear to be dominated by Tardigrada and Rotifera. In some locations, tardigrades dominated (e.g. Gulkana on Alaska, Forni in the Alps); in others, rotifers (e.g. Ecology in maritime Antarctic, Blåisen in Norway). We found, however, that tardigrades and rotifers mostly co-dominated in communities. In contrast, nematodes were absent in material originated from cryoconite holes from 42 glaciers. This absence may be related to a combination of factors including consistently low temperatures, periodic freezing, UV irradiation, nutrient limitation, low solute content, high levels of contamination in cryoconite worldwide (often higher than in other benthic ecosystems) and competition for food. The most likely explanations include the effects of permanently low temperatures in cryoconite holes, which may limit nematode reproduction, or their ability to compete for specific food with glacial rotifers and tardigrades. This observation lays the groundwork for comparisons that can shed light on the limits to multicellular life in the cryosphere.

\section{Acknowledgements}


The authors would like to thank two anonymous reviewers for their valuable comments and corrections. Studies on Arctic glaciers were supported by the National Science Centre under Grant No. NCN 2013/11/N/NZ8/00597 awarded to K.Z. Samples from the Blåisen and Midtdalsbreen glaciers were collected within the Grant [ETANGO] awarded by INTERACT Transnational Access to K.Z. GFF was funded by the European Research Council under the European Community's Horizon 2020 Programme, Grant Agreement no. 772284 (IceCommunities). NT was supported by the funds from JSPS KAKENHI (19H01143 and 20K21840), and from the Arctic Challenge for Sustainability II (ArCS II), Program Grant Number JPMXD1420318865. Work on glaciers from the McMurdo Dry Valleys of Antarctica was supported by the National Science Foundation Award \#1443578 to S.K.S. Fieldwork on Marr Ice Piedmont was realized according to kindly assistance of National scientific foundation (USA) and Palmer station crew. All of the samples were properly collected under the permission of local organizations or governments. The samples from the Ecology Glacier used in the paper were collected and transported based on the logistic support of Henryk Arctowski Polish Antarctic Station. The sampling on Ecology Glacier were initiated by the seminar, 'The role of cryoconite in the functioning of glacial systems' supported by the Centre for Polar Studies (the Leading National Research Centre in Earth Sciences for 2014-2018 No. 03/KNOW2/2014). K.Z. is grateful to Ela Wiejaczka for her support in gaining permission and access to samples from Africa, Joseph Cook for collection of samples in the dark zone of Greenland Ice Sheet, E.Ł. thanks Łukasz Pawłowski for collection of samples from Werenskiold Glacier, and T.J. thanks Matěj Pokorný (Department of Ecology, Charles University) for collection of samples from Blancmange Glacier. Swedish samples were kindly provided to E.P. by Alexandre Anesio.

Achberger, A.M., Michaud, A.B., Vick-Majors, T.J., Christner, B.C., Skidmore, M.L., Priscu, J.C. \& Tranter, M. (2017). Microbiology of subglacial environments. In Psychrophiles: from biodiversity to biotechnology: 83-110. R. Margesin (Ed.). New York: Springer.

Crossref Google Scholar

Albuquerque, E.F., Pinto, A.P.B., Perez, A.Q. \& Veloso, V.G. (2007). Spatial and temporal changes in interstitial meiofauna on a sandy ocean beach of South America. Braz. J. Oceanogr. $55,121-131$.

Crossref Web of Science ${ }^{\circledR}$ Google Scholar

Altiero, T. \& Rebecchi, L. (2001). Rearing tardigrades: results and problems. Zool. Anz. 240, 217-221.

Crossref Web of Science ${ }^{\circledR}$ Google Scholar

Altiero, T., Guidetti, R., Caselli, V., Cesari, M. \& Rebecchi, L. (2011). Ultraviolet radiation tolerance in hydrated and desiccated eutardigrades. J. Zool. Syst. Evol. Res. 49, 104- 110.

Wiley Online Library Web of Science ${ }^{\circledR}$ Google Scholar

Amaral-Zettler, L.A., McCliment, E.A., Ducklow, H.W. \& Huse, S.M. (2009). A method for studying protistan diversity using massively parallel sequencing of V9 hypervariable regions of small-subunit ribosomal RNA genes. PLoS One 4, e6372.

Crossref CAS PubMed Web of Science ${ }^{\circledR}$ Google Scholar

Andriuzzi, W.S., Adams, B.J., Barrett, J.E., Virginia, R.A. \& Wall, D.H. (2018). Observed trends of soil fauna in the Antarctic Dry Valleys: early signs of shifts predicted under climate change. Ecology 99, 312- 321.

Wiley Online Library CAS PubMed Web of Science ${ }^{\circledR G}$ Google Scholar

Aristotle. 350 B.C.E. Historia Animālium. Book VIII, part 2. Athens. Translated by D'Arcy Wentworth Thompson.

Google Scholar 
Aubert, J. (1956). Andiperla willinki n. sp, plécoptère nouveau des Andes de Patagonie. Bull. Soc. Entomol. Suisse 29, 229- 232.

Google Scholar

Azzoni, R.S., Franzetti, A., Fontaneto, D., Zullini, A. \& Ambrosini, R. (2015). Nematodes and rotifers on two Alpine debris-covered glaciers. Ital. J. Zool. 82, 616-623.

Google Scholar

Baccolo, G., Di Mauro, B., Massabò, D., Clemenza, M., Nastasi, M. \& Delmonte, B., Prata, M., Prati, P., Previtali, E. \& Maggi, V. (2017). Cryoconite as a temporary sink for anthropogenic species stored in glaciers. Sci. Rep. 7, 9623.

PubMed Web of Science ${ }^{\circledR}$ Google Scholar

Bertolani, R., Guidetti, R., Jönsson, I.K., Altiero, T., Boschini, D. \& Rebecchi, L. (2004). Experiences with dormancy in tardigrades. J. Lim. 63, 16.

Crossref PubMed Web of Science ${ }^{\circledR}$ Google Scholar

Bezchlebová, J., Černohlávková, J., Lána, J., Sochová, I., Kobetičová, K. \& Hofman, J. (2007). Effects of toxaphene on soil organisms. Ecotoxicol. Environ. Saf. 68, 326- 334.

Crossref CAS PubMed Web of Science ${ }^{\circledR}$ Google Scholar

Bomberg, M., Claesson Liljedahl, L., Lamminmäki, T. \& Kontula, A. (2019). Highly diverse aquatic microbial communities separated by permafrost in Greenland show distinct features according to environmental niches. Front. Microbiol. 10, 1583. https://doi.org/10.3389/fmicb.2019.01583

PubMed Web of Science ${ }^{\circledR}$ Google Scholar

Boothroyd, I. \& Cranston, P. (1999). The 'Ice Worm' - the immature stages, phylogeny and biology of the glacier midge Zelandochlus (Diptera: Chironomidae). Aquat. Insects 21, 303316.

Crossref Web of Science ${ }^{\circledR}$ Google Scholar

Borgonie, G., García-Moyano, A., Litthauer, D., Bert, W., Bester, A., van Heerden, E., Möller, C., Erasmus, M. \& Onstott, T.C. (2011). Nematoda from the terrestrial deep subsurface of South Africa. Nature 474, 79- 82.

Crossref CAS PubMed Web of Science ${ }^{\circledR}$ Google Scholar

Boyer, F., Mercier, C., Bonin, A., Le Bras, Y., Taberlet, P. \& Coissac, E. (2016). Obitools: a unix-inspired software package for DNA metabarcoding. Mol. Ecol. Resour. 16, 176- 182.

Wiley Online Library CAS PubMed Web of Science ${ }^{\circledR}$ Google Scholar

Broady, P.A. (1989). Survey of algae and other terrestrial biota at Edward VII Peninsula, Marie Byrd Land. Antarct. Sci. 1, 215- 224.

Crossref Web of Science ${ }^{\circledR}$ Google Scholar

Buda, J., Łokas, Ł., Pietryka, M., Richter, D., Magowski, W., Iakovenko, N.S., Porazinska, D.L., Budzik, T., Grabiec, M., Grzesiak, J., Klimaszyk, P., Gaca, P. \& Zawierucha, K. (2020). Biotope and biocenosis of cryoconite hole ecosystems on Ecology Glacier in the maritime Antarctic. Sci. Total Environ, 724, 138112.

Crossref CAS PubMed Web of Science ${ }^{\circledR}$ Google Scholar

Caporaso, J.G., Kuczynski, J., Stombaugh, J., Bittinger, K., Bushman, F.D., Costello, E.K., Fierer, N., Peña, A.G., Goodrich, J.K., Gordon, J.I., Huttley, G.A., Kelley, S.T., Knights, D., Koenig, J.E., Ley, R.E., Lozupone, C.A., McDonald, D., Muegge, B.D., Pirrung, M., Reeder, J., Sevinsky, J.R., Tu, P.J.\&Knight, R. (2010). QIIME allows analysis of high-throughput community sequencing data. Nat. Methods 7, 335- 336.

Crossref CAS PubMed Web of Science ${ }^{\circledR G o o g l e ~ S c h o l a r ~}$

Caporaso, J.G., Lauber, C.L., Walters, W.A., Berg-Lyons, D., Huntley, J., Fierer, N., Bauer, M. (2012). Ultra-high-throughput microbial community analysis on the Illumina HiSeq and MiSeq platforms. ISME J. 6, 1621- 1624.

Crossref CAS PubMed Web of Science ${ }^{\circledR G o o g l e ~ S c h o l a r ~}$ 
Cesari, M., McInnes, S.J., Bertolani, R., Rebecchi, L. \& Guidetti, R. (2016). Genetic diversity and biogeography of the south polar water bear Acutuncus antarcticus (Eutardigrada: Hypsibiidae) - evidence that it is a truly pan-Antarctic species. Invertebr. Syst. 30, 635- 649 . Crossref Web of Science ${ }^{\circledR}$ Google Scholar

Christner, B.C., Kvitko, B.H. \& Reeve, J.N. (2003). Molecular identification of bacteria and eukarya inhabiting an Antarctic cryoconite hole. Extremophiles 7, 177- 183.

Crossref CAS PubMed Web of Science ${ }^{\circledR G}$ Google Scholar

Cook, J., Edwards, A., Takeuchi, N. \& Irvine-Fynn, T. (2016). Cryoconite: The dark biological secret of the cryosphere. Prog. Phys. Geog. 40, 66- 111.

Crossref Web of Science ${ }^{\circledR}$ Google Scholar

Coulson, S.J. \& Midgley, N.G. (2012). The role of glacier mice in the invertebrate colonisation of glacial surfaces: the moss balls of the Falljökull, Iceland. Pol. Biol. 35, 1651- 1658.

Crossref Web of Science ${ }^{\circledR}$ Google Scholar

Coulson, S.J., Convey, P., Aakra, K., Aarvik, L., Avila-Jimenez, M.L., Babenko, A., Biersma, E.M, Boström, S., Brittain, J.E., Carlsson, A.M., Christoffersen, K., De Smet, W.H., Ekrem, T., Fjellberg, A., Füreder, L., Gustafsson, D., Gwiazdowicz, D.J., Hansen, L.O., Holmstrup, M., Hullé, M., Kaczmarek, Ł., Kolicka, M., Kuklin, V., Lakka, H.-K., Lebedeva, N., Makarova, O., Maraldo, K., Melekhina, E., Ødegaard, F., Pilskog, H.E., Simon, J.C., Sohlenius, B., Solhøy, T., Søli, G., Stur, E., Tanasevitch, A., Taskaeva, A., Velle, G., Zawierucha, K. \& ZmudczyńskaSkarbek, K. (2014). The terrestrial and freshwater invertebrate biodiversity of the archipelagoes of the Barents Sea; Svalbard, Franz Josef Land and Novaya Zemlya. Soil Biol. Biochem. 68, $440-470$.

Crossref CAS Web of Science ${ }^{\circledR}$ Google Scholar

Crowe, J.I. \& Madin, K.A. (1974). Anhydrobiosis in tardigrades and nematodes. Trans. Am. Microsc. Soc. 93, 513- 524.

Crossref Web of Science ${ }^{\circledR G o o g l e ~ S c h o l a r ~}$

Czechowski, P., White, D., Clarke, L., McKay, A., Cooper, A. \& Stevens, M.I. (2016). Agerelated environmental gradients influence invertebrate distribution in the Prince Charles Mountains, East Antarctica. R. Soc. Open Sci. 3, 160296.

Crossref PubMed Web of Science ${ }^{\circledR G}$ Google Scholar

Dabert, M., Dastych, H. \& Dabert, J. (2015). Molecular data support the dispersal ability of the glacier tardigrade Hypsibius klebelsbergi Mihelčič, 1959 across the environmental barrier (Tardigrada). Mitt. Hamb. Zool. Mus. Inst. 17, 233- 240.

Google Scholar

Darcy, J.L., Gendron, E.M.S., Sommers, P., Porazinska, D.L. \& Schmidt, S.K. (2018). Island biogeography of cryoconite hole bacteria in Antarctica's Taylor valley and around the world. Front. Ecol. Evol. 6, 180. https://doi.org/10.3389/fevo.2018.00180

Crossref Web of Science ${ }^{\circledR}$ Google Scholar

Darwin, C.R. (1859). On the origin of species by means of natural selection, or the preservation of favoured races in the struggle for life. London: John Murray.

Google Scholar

Dastych, H. (1985). West Spitsbergen Tardigrada. Acta Zool. Crac. 28, 169- 214.

Google Scholar

Dastych, H. (1993). Redescription of the cryoconital tardigrade Hypsibius klebelsbergi Mihelcic, 1959, with notes on the microslide collection of the late Dr. F. Michelcic (Tardigrada). Veröff. Mus. Ferdinandeum 73, 5- 12.

Google Scholar

Dastych, H. (2004). Hypsibius thaleri sp. nov., a new species of a glacier-dwelling tardigrade from the Himalayas, Nepal (Tardigrada). Mitt. Hamb. Zool. Mus. Inst. 101, 169- 183.

Google Scholar 
Dastych, H. (2019). Cryobiotus roswithae gen. n., sp. n., a new genus and species of glacierdwelling tardigrades from Northern Norway (Tardigrada, Panarthropoda). Entomol. Heute 31, 95- 111 .

Google Scholar

Dastych, H., Kraus, H.J. \& Thaler, K. (2003). Redescription and notes on the biology of the glacier tardigrade Hypsibius klebelsbergi Mihelcic, 1959 (Tardigrada), based on material from Ötztal Alps. Austria. Mitt. Hamb. Zool. Mus. Inst. 100, 73- 100.

Google Scholar

De Smet, W.H. \& Van Rompu, E.A. (1994). Rotifera and Tardigrada from some cryoconite holes on a Spitsbergen (Svalbard) glacier. Belg. J. Zool. 124, 27- 37.

Web of Science ${ }^{\circledR G}$ Google Scholar

Dial, C.R., Dial, R.J., Saunders, R., Lang, S.A., Lee, B., Wimberger, P., Dinapoli, M.S., Egiazarov, A.S., Gipple, S.L., Maghirang, M.R., Swartley-McArdle, D.J., Yudkovitz, S.R. \& Shain, D.H. (2012). Historical biogeography of the North American glacier ice worm, Mesenchytraeus solifugus (Annelida: Oligochaeta: Enchytraeidae). Mol. Phylo. Evol. 63, 577584.

PubMed Web of Science ${ }^{\circledR G o o g l e ~ S c h o l a r ~}$

Dial, R.J., Becker, M., Hope, A.G., Dial, C.R., Thomas, J., Slobodenko, K.A., Golden, T.S., Shain, D.H. (2016). The role of temperature in the distribution of the glacier ice worm, Mesenchytraeus solifugus (Annelida: Oligochaeta: Enchytraeidae). Arct. Antarct. Alp. Res. 48, 199- 211.

Crossref Web of Science ${ }^{\circledR}$ Google Scholar

Drygalski, E.V. (1897). Die Kryoconitlcher. In Grönland- Expedition der Gesellschaft für Erdkunde zu Berlin 1891-1893: 93- 103. W.H. Kuhl (Ed.). Berlin: Heeausgegebex von dek.

Google Scholar

Dubnick, A., Kazemi, S., Sharp, M., Wadham, J., Hawkings, J., Beaton, A. \& Lanoil, B. (2017). Hydrological controls on glacially exported microbial assemblages: subglacial hydrology and microbiology. J. Geophys. Res. Biogeosci. 122, 1049- 1061.

Wiley Online Library CAS Web of Science ${ }^{\circledR}$ Google Scholar

Edgar, R.C. (2010). Search and clustering orders of magnitude faster than BLAST. Bioinformatics 26, 2460- 2461.

Crossref CAS PubMed Web of Science ${ }^{\circledR}$ Google Scholar

Edwards, A., Pachebat, J.A., Swain, M., Hegarty, M., Hodson, A.J., Irvine-Fynn, T.D.L., Rassner, S.M.E. \& Sattler, B. (2013). A metagenomic snapshot of taxonomic and functional diversity in an alpine glacier cryoconite ecosystem. Environ. Res. Lett. 8, 1- 11 .

Crossref Web of Science ${ }^{\circledR}$ Google Scholar

Faurby, S., Jørgensen, A., Kristensen, R.M. \& Funch, P. (2012). Distribution and speciation in marine intertidal tardigrades. J. Biogeo. 39, 1596- 1607.

Wiley Online Library Web of Science ${ }^{\circledR}$ Google Scholar

Ferrario, C., Pittino, F., Tagliaferri, I., Gandolfi, I., Bestetti, G., Azzoni, R.S., Diolaiuti, G., Franzetti, A., Ambrosini, R. \& Villa, S. (2017). Bacteria contribute to pesticide degradation in cryoconite holes in an Alpine glacier. Environ. Pollut. 230, 919- 926.

Crossref CAS PubMed Web of Science ${ }^{\circledR}$ Google Scholar

Fjellberg, A. (2010). Cryophilic Isotomidae (Collembola) of the Northwestern Rocky Mountains, U.S.A. Zootaxa 2513, 27- 49.

Google Scholar

Fontaneto, D. (2019). Long-distance passive dispersal in microscopic aquatic animals. Mov. Ecol. 7, 10. https://doi.org/10.1186/s40462-019-0155-7

Crossref PubMed Web of Science ${ }^{\circledR}$ Google Scholar 
Forró, L., Korovchinsky, N.M., Kotov, A.A. \& Petrusek, A. (2008). Global diversity of cladocerans (Cladocera; Crustacea) in freshwater. Hydrobiologia 595, 177- 184.

Crossref Web of Science ${ }^{\circledR}$ Google Scholar

Fountain, A.G., Tranter, M., Nylen, T.H., Lewis, K.J. \& Mueller, D.R. (2004). Evolution of cryoconite holes and their contribution to meltwater runoff from glaciers in the McMurdo Dry Valleys, Antarctica. J. Glaciol. 50, 35- 45.

Crossref Web of Science ${ }^{\circledR}$ Google Scholar

Franzetti, A., Navarra, F., Tagliaferri, I., Gandolfi, I., Bestetti, G., Minora, U., Azzoni, R.S., Diolaiuti, G., Smiraglia, C. \& Ambrosini, R. (2017). Potential sources of bacteria colonizing the cryoconite of an Alpine glacier. PLoS One 12, e0174786.

Crossref PubMed Web of Science ${ }^{\circledR}$ Google Scholar

Gerdel, R.W. \& Drouet, F. (1960). The cryoconite of the Thule area, Greenland. Trans. Am. Microsc. Soc. 79, 256- 272.

Crossref Google Scholar

Goodman, D. (1971). Ecological investigations of ice worms on Casement Glacier, Southeastern Alaska (No. 39). Columbus: Ohio State University Research Foundation.

Crossref Google Scholar

Grøngaard, A., Pugh, P.J. \& McInnes, S.J. (1999). Tardigrades, and other cryoconite biota, on the Greenland ice sheet. Zool. Anz. 238, 211-214.

Web of Science ${ }^{\circledR G}$ Google Scholar

Grzelak, K., Gluchowska, M., Gregorczyk, K., Winogradow, A. \& Weslawski, J.M. (2016).

Nematode biomass and morphometric attributes as biological indicators of local environmental conditions in Arctic fjords. Ecol. Ind. 69, 368- 380.

Crossref Web of Science ${ }^{\circledR}$ Google Scholar

Guardiola, M., Uriz, M.J., Taberlet, P., Coissac, E., Wangensteen, O.S. \& Turon, X. (2015).

Deep-Sea, deep-sequencing: metabarcoding extracellular DNA from sediments of marine canyons. PLoS One 10, e0139633.

Crossref PubMed Web of Science ${ }^{\circledR}$ Google Scholar

Guidetti, R., Rizzo, A.M., Altiero, T. \& Rebecchi, L. (2012). What can we learn from the toughest animals of the Earth? Water bears (tardigrades) as multicellular model organisms in order to perform scientific preparations for lunar exploration. Planet. Space Sci. 74, 97- 102.

Crossref Web of Science ${ }^{\circledR}$ Google Scholar

Guil, N., Sánchez-Moreno, S. \& Machordom, A. (2009). Local biodiversity patterns in micrometazoans: Are tardigrades everywhere? Syst. Biodivers. 7, 259- 268.

Crossref Web of Science ${ }^{\circledR}$ Google Scholar

Hart, D.D. \& Robinson, C.T. (1990). Resource limitation in a stream community: phosphorus enrichment effects on periphyton and grazers. Ecology 71, 1494- 1502.

Wiley Online Library Web of Science ${ }^{\circledR G}$ Google Scholar

Hinden, H., Oertli, B., Menetrey, N., Sager, L. \& Lachavanne, J.B. (2005). Alpine pond biodiversity: what are the related environmental variables? Aquat. Conserv. 15, 613-624.

Wiley Online Library Web of Science ${ }^{\circledR G o o g l e ~ S c h o l a r ~}$

Hodda, M. (2007). Phylum Nematoda. Zootaxa 1668, 265- 293. https://doi.org/10.11646/zootaxa.1668.1.14

Crossref Web of Science ${ }^{\circledR}$ Google Scholar

Hodson, A.J. (2014). Understanding the dynamics of black carbon and associated contaminants in glacial systems. Wiley Interdiscip. Rev. 1, 141- 149.

Wiley Online Library CAS Google Scholar

Hodson, A.J., Anesio, A.M., Tranter, M., Fountain, A., Osborn, M., Priscu, J., Laybourn-Parry, J. \& Sattler, B. (2008). Glacial ecosystems. Ecol. Monogr. 78, 41- 67.

Wiley Online Library Web of Science ${ }^{\circledR}$ Google Scholar 
Holland, A.T., Williamson, C.J., Sgouridis, F., Tedstone, A.J., McCutcheon, J., Cook, J.M., Poniecka, E., Yallop, M.L., Tranter, M., Anesio, A.M.; The Black \& Bloom Group (2019). Nutrient cycling in supraglacial environments of the Dark Zone of the Greenland Ice Sheet. Biogeoscience 16, 3283-3296.

Crossref CAS Web of Science ${ }^{\circledR G}$ Google Scholar van den Hoogen, J., Geisen, S., Routh, D., Ferris, H., Traunspurger, W., Wardle, D.A., de Goede, R.G.M., Adams, B.J., Ahmad, W., Andriuzzi, W.S., Bardgett, R.D., Bonkowski, M., Campos-Herrera, R., Cares, J.E., Caruso, T., de Brito Caixeta, L., Chen, X., Costa, S.R., Creamer, R., Mauro da Cunha Castro, J., Dam, M., Djigal, D., Escuer, M., Griffiths, B.S., Gutiérrez, C., Hohberg, K., Kalinkina, D., Kardol, P., Kergunteuil, A., Korthals, G., Krashevska, V., Kudrin, A.A., Li, Q., Liang, W., Magilton, M., Marais, M., Martín, J.A.R., Matveeva, E., Mayad, E.H., Mulder, C., Mullin, P., Neilson, R., Nguyen, T.A.D., Nielsen, U.N., Okada, H., Rius, J.E.P., Pan, K., Peneva, V., Pellissier, L., Carlos Pereira da Silva, J., Pitteloud, C., Powers, T.O., Powers, K., Quist, C.W., Rasmann, S., Moreno, S.S., Scheu, S., Setälä, H., Sushchuk, A., Tiunov, A.V., Trap, J., van der Putten, W., Vestergård, M., Villenave, C., Waeyenberge, L., Wall, D.H., Wilschut, R., Wright, D.G., Yang, J.-I. \& Crowther, T.W. (2019). Soil nematode abundance and functional group composition at a global scale. Nature 572, 194 198.

Crossref PubMed Web of Science ${ }^{\circledR}$ Google Scholar

Hussain, S., Boland, S., Baeza-Squiban, A., Hamel, R., Thomassen, L.C., Martens, J.A., BillonGalland, M.A., Fleury-Feith, J., Moisan, F., Pairon, J.-C. \&Marano, F. (2009). Oxidative stress and proinflammatory effects of carbon black and titanium dioxide nanoparticles: role of particle surface area and internalized amount. Toxicology 260, 142- 149.

Crossref CAS PubMed Web of Science ${ }^{\circledR}$ Google Scholar

Iakovenko, N.S., Smykla, J., Convey, P., Kašparová, E., Kozereetska, I.A., Trokhymets, V., Dykyy, I., Plewka, M., Devetter, M., Duriš, Z. \& Janko, K. (2015). Antarctic bdelloid rotifers: diversity, endemism and evolution. Hydrobiologia 761, 5- 43.

Crossref Web of Science ${ }^{\circledR G}$ Google Scholar

Janiec, K. (1996). The comparison of freshwater invertebrates of Spitsbergen (Arctic) and King George Island (Antarctic). Pol. Polar Res. 17, 173- 202.

Google Scholar

Jönsson, K.I. \& Wojcik, A. (2017). Tolerance to X-rays and Heavy Ions (Fe, He) in the Tardigrade Richtersius coronifer and the Bdelloid Rotifer Mniobia russeola. Astrobiology 17, $163-167$.

Crossref PubMed Web of Science ${ }^{\circledR G o o g l e ~ S c h o l a r ~}$

Jørgensen, A., Møbjerg, N. \& Kristensen, R.M. (2007). A molecular study of the tardigrade Echiniscus testudo (Echiniscidae) reveals low DNA sequence diversity over a large geographical area. J. Limnol. 66, 77.

Crossref Web of Science ${ }^{\circledR}$ Google Scholar

Jungblut, A.D., Vincent, W.F. \& Lovejoy, C. (2012). Eukaryotes in Arctic and Antarctic cyanobacterial mats. FEMS Microbiol. Ecol. 82, 416- 428.

Wiley Online Library CAS PubMed Web of Science ${ }^{\circledR}$ Google Scholar

Kaczmarek, Ł., Michalczyk, Ł. \& McInnes, S.J. (2016). Annotated zoogeography of nonmarine Tardigrada. Part III: North America and Greenland. Zootaxa 4203, 1- 249.

Web of Science ${ }^{\circledR}$ Google Scholar

Khan, A.L., Wagner, S., Jaffe, R., Xian, P., Williams, M., Armstrong, R. \& McKnigt, D. (2017). Dissolved black carbon in the global cryosphere: Concentrations and chemical signatures. Geophys. Res. Let. 44, 6226- 6234.

Wiley Online Library CAS Web of Science ${ }^{\circledR}$ Google Scholar 
Kikuchi, Y. (1994). Glaciella, a new genus of freshwater Canthocamptidae (Copepoda, Harpacticoida) from a glacier in Nepal, Himalayas. Hydrobiologia 292, $59-66$.

Crossref Google Scholar

Kohshima, S. (1984). A novel cold tolerant insect found in a Himalayan glacier. Nature 310, 225- 227.

Crossref Web of Science ${ }^{\circledR G}$ Google Scholar

Kohshima, S. (1985). Patagonian glaciers as insect habitats. In Glaciological studies in Patagonia Northern Icefield: 94- 99. C. Nokajima (Ed.). Kyoto: Data Center for Glacier Research Japanese Society of Snow and Ice.

Google Scholar

Kolicka, M., Dabert, M., Dabert, J., Kånneby, T. \& Kisielewski, J. (2016). Bifidochaetus, a new Arctic genus of freshwater Chaetonotida (Gastrotricha) from Spitsbergen revealed by an integrative taxonomic approach. Invertebr. Syst. 30, 398- 419.

Crossref Web of Science ${ }^{\circledR}$ Google Scholar

Kristensen, R.M. (2002). An Introduction to Loricifera, Cycliophora, and Micrognathozoa. Int. Compar. Biol. 42, 641- 651.

Crossref PubMed Web of Science ${ }^{\circledR}$ Google Scholar

Liu, Y., Vick-Majors, T.J., Priscu, J.C., Yao, T., Kang, S., Liu, K., Cong, Z., Xiong, J. \& Li, Y. (2017). Biogeography of cryoconite bacterial communities on glaciers of the Tibetan Plateau. FEMS Microbiol. Ecol. 93, fix072.

Web of Science ${ }^{\circledR}$ Google Scholar

Łokas, E., Zaborska, A., Kolicka, M., Różycki, M. \& Zawierucha, K. (2016). Accumulation of atmospheric radionuclides and heavy metals in cryoconite holes on an Arctic glacier. Chemosphere 160, 162- 172 .

Crossref CAS PubMed Web of Science ${ }^{\circledR G o o g l e ~ S c h o l a r ~}$

Łokas, E., Zawierucha, K., Cwanek, A., Szufa, K., Gaca, P., Mietelski, J.W. \& Tomankiewicz, E. (2018). The sources of high airborne radioactivity in cryoconite holes from the Caucasus (Georgia). Sci. Rep. 8, 10802.

PubMed Web of Science ${ }^{\circledR G}$ Google Scholar

Lorimore, S.A., Kadhim, M.A., Pocock, D.A., Papworth, D., Stevens, D.L., Goodhead, D.T. \& Wright, E.G. (1998). Chromosomal instability in the descendants of unirradiated surviving cells after $\alpha$-particle irradiation. Proc. Natl. Acad. Sci. USA 95, 5730- 5733.

Crossref CAS PubMed Web of Science ${ }^{\circledR}$ Google Scholar

Lutz, S., Ziolkowski, L.A. \& Benning, L.G. (2019). The biodiversity and geochemistry of cryoconite holes in Queen Maud Land, East Antarctica. Microorganisms 7, 160.

Crossref CAS Web of Science ${ }^{\circledR}$ Google Scholar

MacArthur, R.H. \& Wilson, E.O. (1967). The theory of island biogeography: 224. Princeton: Princeton University Press.

Google Scholar

Maccario, L., Sanguino, L., Vogel, T.M. \& Larose, C. (2015). Snow and ice ecosystems: not so extreme. Res. Microbiol. 166, 782- 795.

Crossref PubMed Web of Science ${ }^{\circledR}$ Google Scholar

Majdi, N. \& Traunspurger, W. (2015). Free-living nematodes in the freshwater food web: a review. J. Nemat. 47, 28- 44.

PubMed Web of Science ${ }^{\circledR}$ Google Scholar

Makowska, N., Zawierucha, K., Mokracka, J. \& Koczura, R. (2016). First report of microorganisms of Caucasus glaciers (Georgia). Biologia 71, 620-625.

CAS Web of Science ${ }^{\circledR}$ Google Scholar 
Michelutti, N., Wolfe, A.P., Vinebrooke, R.D., Rivard, B. \& Briner, J.P. (2005). Recent primary production increases in arctic lakes. Geophys. Res. Let. 32, L19715. https://doi.org/10.1029/2005GL023693

Wiley Online Library Web of Science ${ }^{\circledR G o o g l e ~ S c h o l a r ~}$

Michiels, I.C. \& Traunspurger, W. (2005). Impact of resource availability on species composition and diversity in freshwater nematodes. Oecologia 142, 98- 103.

Crossref PubMed Web of Science ${ }^{\circledR G o o g l e ~ S c h o l a r ~}$

Mihelčič, F. (1959). Zwei neue Tardigraden aus der Gattung Hypsibius Thulin aus Osttirol (Österreich). Systematisches zur Gattung Hypsibius Thulin. Zool. Anz. 163, 254- 261.

Google Scholar

Monge-Najera, J. (1995). Phylogeny, biogeography and reproductive trends in the Onychophora. Zool. J. Linn. Soc. 114, 21-60.

Wiley Online Library Web of Science ${ }^{\circledR}$ Google Scholar

Mueller, D.R., Vincent, W.F., Pollard, W.H. \& Fristen, C.H. (2001). Glacial cryoconite ecosystems: a bipolar comparison of algal communities and habitats. Nov. Hedw. Beih. 123, $173-197$.

Google Scholar

Muñoz, I., Gaudes, A., Sabater, S. \& Vilalta, E. (2006). The nematode community in cyanobacterial biofilms in the river Llobregat, Spain. Nematology 8, 909-919.

Web of Science ${ }^{\circledR G}$ Google Scholar

Murakami, T., Segawa, T., Takeuchi, N., Barcaza Sepúlveda, G., Labarca, P., Kohshima, S. \& Hongoh, Y. (2018). Metagenomic analyses highlight the symbiotic association between the glacier stonefly Andiperla willinki and its bacterial gut community. Environ. Microbiol. 20, 4170- 4183.

Wiley Online Library CAS PubMed Web of Science®Google Scholar

Nascimento, F.J.A., Karlson, A.M.L., Näslund, J. \& Gorokhova, E. (2009). Settling cyanobacterial blooms do not improve growth conditions for soft bottom meiofauna. J. Exp. Mar. Biol. Ecol. 368, 138- 146.

Crossref Web of Science ${ }^{\circledR}$ Google Scholar

Nelson, D.R., Bartels, P.J. \& Guil, N. (2018). Tardigrade ecology. In Water bears: the biology of tardigrades, Vol. 2: 163-210. Schill, R.O. (Ed.). Berlin: Zoological Monographs Springer.

Google Scholar

Nkem, J.N., Virginia, R.A., Barrett, J.E., Wall, D.H. \& Li, G. (2006a). Salt tolerance and survival thresholds for two species of Antarctic soil nematodes. Pol. Biol. 29, 643-651.

Crossref Web of Science ${ }^{\circledR}$ Google Scholar

Nkem, J.N., Wall, D.H., Virginia, R.A., Barrett, J.E., Broos, E.J., Porazinska, D.L. \& Adams, B.J. (2006b). Wind dispersal of soil invertebrates in the McMurdo Dry Valleys, Antarctica. Pol. Biol. 29, 346- 352 .

Crossref Web of Science ${ }^{\circledR}$ Google Scholar

Odell, N. (1956). So-called 'Glacier-Worms' in New Zealand. Nature 177, 534.

PubMed Web of Science ${ }^{\circledR}$ Google Scholar

Overhoff, A., Freckman, D.W. \& Virginia, R.A. (1993). Life cycle of the microbivorous Antarctic Dry Valley Scottnema lindsayae (Timm 1971). Pol. Biol. 13, 151- 156.

Crossref Web of Science ${ }^{\circledR}$ Google Scholar

Pansu, J., Giguet-Covex, C., Ficetola, G.F., Gielly, L., Boyer, F., Zinger, L., Arnaud, F., Poulenard, J., Taberlet, P. \& Choler, P. (2015). Reconstructing long-term human impacts on plant communities: an ecological approach based on lake sediment DNA. Mol. Ecol. 24, 14851498.

Wiley Online Library PubMed Web of Science ${ }^{\circledR G o o g l e ~ S c h o l a r ~}$ 
Parducci, L., Bennet, K.D., Ficetola, G.F., Alsos, I.G., Suyama, Y., Wood, J.R. \& Pedersen, M.W. (2017). Ancient plant DNA in lake sediments. New Phytol. 214, 924- 942.

Wiley Online Library CAS PubMed Web of Science ${ }^{\circledR}$ Google Scholar

Peters, L. \& Traunspurger, W. (2005). Species distribution of free-living nematodes and other meiofauna in littoral periphyton communities of lakes. Nematology 7, 267-280.

Crossref Web of Science ${ }^{\circledR}$ Google Scholar

Pittino, F., Maglio, M., Gandolfi, I., Azzoni, R.S., Diolaiuti, G., Ambrosini, R. \& Franzetti, A. (2018). Bacterial communities of cryoconite holes of a temperate alpine glacier show both seasonal trends and year-to-year variability. Ann. Glaciol. 59, 1-9.

Crossref Web of Science ${ }^{\circledR}$ Google Scholar

Poniecka, E.A., Bagshaw, E.A., Tranter, M., Sass, H., Williamson, C.J., Anesio, A.M.; Black and Bloom Team (2018). Rapid development of anoxic niches in supraglacial ecosystems. Arct. Antarct. Alp. Res. 50, S100015.

Crossref Web of Science ${ }^{\circledR}$ Google Scholar

Porazinska, D.L., Fountain, A.G., Nylen, T.H., Tranter, M., Virginia, R.A. \& Wall, D.H. (2004). The biodiversity and biogeochemistry of cryoconite holes from McMurdo Dry Valley glaciers, Antarctica. Arct. Antarct. Alp. Res. 36, 84- 91.

Crossref Web of Science ${ }^{\circledR}$ Google Scholar

Porazinska, D.L., Farrer, E.C., Spasojevic, M.J., Bueno de Mesquita, C.P., Sartwell, S.A., Smith, J.G., Schmidt, S.K. (2018). Plant diversity and density predict belowground diversity and function in an early successional alpine ecosystem. Ecology 99, 1942- 1952.

Wiley Online Library PubMed Web of Science ${ }^{\circledR}$ Google Scholar

Ptatscheck, C., Gansfort, B. \& Traunspurger, W. (2018). The extent of wind-mediated dispersal of small metazoans, focusing nematodes. Sci. Rep. 8, 6814.

Crossref PubMed Web of Science ${ }^{\circledR G}$ Google Scholar

Quast, C., Pruesse, E., Yilmaz, P., Gerken, J., Schweer, T., Yarza, P., Peplies, J., Glöckner, F.O. (2013). The SILVA ribosomal RNA gene database project: Improved data processing and web-based tools. Nucl. Acids. Res. 41, D590- D596.

Crossref CAS PubMed Web of Science ${ }^{\circledR G o o g l e ~ S c h o l a r ~}$

Ramazzotti, G. (1968). Tardigradi dei pozzetti glaciali di fusione (Kryokonitlöcher) dell'Himalaya, Vol. 3: 1-3. Khumbu Himal: Innsbrück, München: Universitätsverlag, Wagner. Google Scholar

Ramazzotti, G. \& Maucci, W. (1983). II Philum Tardigrada (III. edizione riveduta e aggiornata). Mem. Ist. Ital. Idrobiol. 41, 1- 1016.

Google Scholar

Ristau, K. \& Traunspurger, W. (2011). Relation between nematode communities and trophic state in southern Swedish lakes. Hydrobiologia 663, 121- 133.

Crossref Web of Science ${ }^{\circledR}$ Google Scholar

Rognes, T., Flouri, T., Nichols, B., Quince, C. \& Mahé, F. (2016). VSEARCH: a versatile open source tool for metagenomics. PeerJ 4, e2584.

Crossref PubMed Web of Science ${ }^{\circledR}$ Google Scholar

Säwström, C., Mumford, P., Marshall, W., Hodson, A. \& Laybourn-Parry, J. (2002). The microbial communities and primary productivity of cryoconite holes in an Arctic glacier (Svalbard 79॰ N). Polar Biol. 25, 591- 596.

Crossref Web of Science ${ }^{\circledR G o o g l e ~ S c h o l a r ~}$

Schill, R.O. \& Hengherr, S. (2019). Environmental adaptations: desiccation tolerance. In Water bears: the biology of tardigrades: 273-293. R.O. Schill (Ed.). Berlin: Springer.

Google Scholar 
Schneider, A., Wetterich, S., Schirrmeister, L., Herzschuh, U., Meyer, H. \& Pestryakova, L.A. (2016). Freshwater ostracods (Crustacea) and environmental variability of polygon ponds in the tundra of the Indigirka Lowland, north-east Siberia. Pol. Res. 35, 25225.

Crossref Web of Science ${ }^{\circledR}$ Google Scholar

Schwarz, A.M.J., Green, J.D., Green, T.G.A. \& Seppelt, R.D. (1993). Invertebrates associated with moss communities at Canada Glacier, southern Victoria Land, Antarctica. Pol. Biol. 13, $157-162$.

Crossref Web of Science ${ }^{\circledR}$ Google Scholar

Segawa, T., Yonezawa, T., Edwards, A., Akiyoshi, A., Tanaka, S., Uetake, J., Irvine-Fynn, T., Fukui, K., Li, Z. \&Takeuchi, N. (2017). Biogeography of cryoconite forming cyanobacteria on polar and Asian glaciers. J. Biogeogr. 44, 2849- 2861.

Wiley Online Library Web of Science ${ }^{\circledR G}$ Google Scholar

Segawa, T., Matsuzaki, R., Takeuchi, N., Akiyoshi, A., Navarro, F., Sugiyama, S., Yonezawa, T. \& Mori, H. (2018). Bipolar dispersal of red-snow algae. Nat. Comm. 9, 3094. https://doi.org/10.1038/s41467-018-05521-w

Crossref PubMed Web of Science ${ }^{\circledR G o o g l e ~ S c h o l a r ~}$

Segers, H. (2008). Global diversity of rotifers in freshwater. Hydrobiologia 595, 49- 59.

Crossref Web of Science ${ }^{\circledR}$ Google Scholar

Shain, D.H., Halldórsdóttir, K., Pálsson, F., Aðalgeirsdóttir, G., Gunnarsson, A., Jónsson, P., Lang, S.A., Pálsson, H.S., Stein órssson, S. \& Arnason, E. (2016). Colonization of maritime glacier ice by bdelloid Rotifera. Mol. Phylo. Evol. 98, 280- 287.

Crossref PubMed Web of Science ${ }^{\circledR}$ Google Scholar

Shaw, E.A., Adams, B.J., Barrett, J.E., Lyons, W.B., Virginia, R.A. \& Wall, D.H. (2018). Stable isotopes reveal soil food web structure and the nematode, Eudorylaimus antarcticus, as an omnivore-predator in Taylor Valley, Antarctica. Pol. Biol. 41, 1013- 1018.

Crossref Web of Science ${ }^{\circledR G}$ Google Scholar

Sheath, R.G. (1986). Seasonality of phytoplankton in northern tundra ponds. Hydrobiologia $138,75-83$.

Crossref Web of Science ${ }^{\circledR}$ Google Scholar

Sohlenius, B. (1977). Numbers, biomass and respiration of Nematoda, Rotatoria and Tardigrada in a 120-year-old Scots pine forest at Ivantjärnsheden, Central Sweden. Technical Report Swedish Coniferous Forest Project (Sweden) no. 9, ISSN : 0346-7708.

Google Scholar

Sohlenius, B. (1979). A carbon budget for nematodes, rotifers and tardigrades in a Swedish coniferous forest soil. Holarct. Ecol. 2, 30- 40.

CAS Google Scholar

Sohlenius, B., Boström, S. \& Jönsson, I. (2004). Occurrence of nematodes, tardigrades and rotifers on ice-free areas in East Antarctica. Pedobiologia 48, 395- 408.

Crossref Web of Science ${ }^{\circledR}$ Google Scholar

Sømme, L. (1996). Anhydrobiosis and cold tolerance in tardigrades. Eur. J. Entomol. 93, 349357.

Web of Science ${ }^{\circledR G}$ Google Scholar

Sommers, P., Darcy, J.L., Gendron, E.M.S., Stanish, L.F., Bagshaw, E.A., Porazinska, D.L. \& Schmidt, S.K. (2018). Diversity patterns of microbial eukaryotes mirror those of bacteria in Antarctic cryoconite holes. FEMS Microbiol. Ecol. 94(1). https://doi.org/10.1093/femsec/fix167

PubMed Web of Science ${ }^{\circledR G}$ Google Scholar

Sommers, P., Darcy, J.L., Porazinska, D.L., Gendron, E.M.S., Fountain, A.G., Zamora, F., Vincent, K., Cawley, K.M., Solon, A.J., Vimercati, L., Ryder, J. \& Schmidt, S.K. (2019). Comparison of microbial communities in the sediments and water columns of frozen cryoconite 
holes in the McMurdo Dry Valleys, Antarctica. Front. Microbiol. 10, 65. https://doi.org/10.3389/fmicb.2019.00065

PubMed Web of Science ${ }^{\circ}$ Google Scholar

Steinböck, O. (1936). Über Kryokonitöcher under ihre biologische Bedentung. Z. Gletsch. 24, $1-21$.

Google Scholar

Stibal, M. \& Tranter, M. (2007). Laboratory investigation of inorganic carbon uptake by cryoconite debris from Werenskioldbreen, Svalbard. J. Geophys. Res. 112, G04S33.

Wiley Online Library CAS Web of Science ${ }^{\circledR}$ Google Scholar

Stibal, M., Lawson, E.C., Lis, G.P., Mak, K.M., Wadham, J.L. \& Anesio, A.M. (2010). Organic matter content and quality in supraglacial debris across the ablation zone of the Greenland ice sheet. Ann. Glaciol. 51, 1-8.

Crossref CAS Web of Science ${ }^{\circledR}$ Google Scholar

Stibal, M., Schostag, M., Cameron, K.A., Hansen, L.H., Chandler, D.M., Wadham, J.L. \& Jacobsen, C.S. (2015). Different bulk and active bacterial communities in cryoconite from the margin and interior of the Greenland ice sheet. Environ. Microbiol. Rep. 7, 293- 300.

Wiley Online Library CAS PubMed Web of Science ${ }^{\circledR G}$ Google Scholar

Stibal, M., Bradley, J.A., Edwards, A., Hotaling, S., Zawierucha, K., Rosvold, J., Lutz, S., Cameron, K.A., Mikucki, J.A., Kohler, T.J., Šabacká, M. \& Anesio, A.M. (2020). Glacial ecosystems are essential to understanding biodiversity responses to glacier retreat. Nat. Ecol. Evol. 4, 686-687.

Crossref PubMed Web of Science ${ }^{\circledR G}$ Google Scholar

Taberlet, P., Bonin, A., Zinger, L. \& Coissac, E. (2018). Environmental DNA: For biodiversity research and monitoring. Oxford: Oxford University Press.

Crossref Google Scholar

Takeuchi, N. (2002). Optical characteristics of cryoconite (surface dust) on glaciers: the relationship between light absorbency and the property of organic matter contained in the cryoconite. Ann. Glaciol. 34, 409- 414.

Crossref CAS Web of Science ${ }^{\circledR G}$ Google Scholar

Takeuchi, N. \& Kohshima, S. (2004). A snow algal community on Tyndall glacier in the Southern Patagonia Icefield, Chile. Arct. Antarct. Alp. Res. 36, 92- 99.

Crossref Web of Science ${ }^{\circledR}$ Google Scholar

Takeuchi, N., Kohshima, S., Yoshimura, Y., Sekto, K. \& Fujita, K. (2000). Characteristics of cryoconite holes on a Himalayan glacier, Yala Glacier Central Nepal. Bull. Glaciol. Res. 17, $51-59$.

Google Scholar

Takeuchi, N., Nishiyama, H. \& Li, Z. (2010). Structure and formation process of cryoconite granules on Ürümqi glacier No. 1, Tien Shan, China. Ann. Glaciol. 51, 9- 14.

Crossref Web of Science ${ }^{\circledR}$ Google Scholar

Treonis, A.M. (2005). Soil nematodes and desiccation survival in the extreme arid environment of the antarctic dry valleys. Int. Comp. Biol. 45, 741- 750.

Crossref PubMed Web of Science ${ }^{\circledR}$ Google Scholar

Uetake, J., Tanaka, S., Segawa, T., Takeuchi, T., Nagatsuka, N., Motoyama, H. \& Aoki, T. (2016). Microbial community variation in cryoconite granules on Qaanaaq Glacier, NW Greenland. FEMS Microbiol. Ecol. 92, fiw 127.

Crossref PubMed Web of Science ${ }^{\circledR}$ Google Scholar

Urabe, J., Clasen, J. \& Sterner, R.W. (1997). Phosphorus limitation of Daphnia growth: is it real? Limnol. Oceanogr. 42, 1436- 1443.

Wiley Online Library CAS Web of Science ${ }^{\circledR G o o g l e ~ S c h o l a r ~}$ 
Velasco-Castrillón, A., Gibson, J.A.E. \& Stevens, M.I. (2014). A review of current Antarctic limno-terrestrial microfauna. Pol. Biol. 37, 1517- 1531.

Crossref Web of Science ${ }^{\circledR}$ Google Scholar

Velasco-Castrillón, A., Hawes, I. \& Stevens, M.I. (2018). 100 years on: a re-evaluation of the first discovery of microfauna from Ross Island, Antarctica. Antarct. Sci. 30, 209- 219.

Crossref Web of Science ${ }^{\circledR}$ Google Scholar

Vonnahme, T.R., Devetter, M., Zárský, J.D., Sabacká, M. \& Elster, J. (2016). Controls on microalgal community structures in cryoconite holes upon high Arctic glaciers, Svalbard. Biogeoscience 13, 659-674.

Crossref CAS Web of Science ${ }^{\circledR G o o g l e ~ S c h o l a r ~}$

Wharton, D.A. (1986). A functional biology of nematodes: 192. London: Croom Helm.

Google Scholar

Wharton, D.A. (2003). The environmental physiology of Antarctic terrestrial nematodes: a review. J. Comp. Physiol. B 173, 621-628.

Crossref CAS PubMed Web of Science ${ }^{\circledR}$ Google Scholar

Wharton, D.A. \& Raymond, M.R. (2015). Cold tolerance of the Antarctic nematodes Plectus murrayi and Scottnema lindsayae. J. Comp. Physiol. B 185, 281- 289.

Crossref CAS PubMed Web of Science ${ }^{\circledR}$ Google Scholar

Wharton, D.A., McKay, C.P., Simmons, G.M. \& Parker, P.C. (1985). Cryoconite holes on glaciers. Biogeoscience 35, 499- 503.

Google Scholar

Wu, T., Ayres, E., Bardgett, R.D., Wall, D.H. \& Garey, J.R. (2011). Molecular study of worldwide distribution and diversity of soil animals. Proc. Natl. Acad. Sci. USA 108, 1772017725 .

Crossref CAS PubMed Web of Science ${ }^{\circledR}$ Google Scholar

Yde, J.C., Bárcena, T.G. \& Finster, K.W. (2011). Subglacial and proglacial ecosystem responses to climate change. Clim. Chang. Geophysical Foundations and Ecological Effects, Juan Blanco and Houshang Kheradmand, IntechOpen. https://doi.org/10.5772/24236

Google Scholar

Zawierucha, K., Kolicka, M., Takeuchi, N. \& Kaczmarek, Ł. (2015). What animals can live in cryoconite holes? A faunal review: cryoconite holes fauna. J. Zool. 295, 159- 169.

Wiley Online Library Web of Science ${ }^{\circledR}$ Google Scholar

Zawierucha, K., Ostrowska, M., Vonnahme, T.R., Devetter, M., Nawrot, A.P., Lehmann, S. \& Kolicka, M. (2016). Diversity and distribution of Tardigrada in Arctic cryoconite holes. J. Limnol. 75, 545- 559.

Web of Science ${ }^{\circledR G o o g l e ~ S c h o l a r ~}$

Zawierucha, K., Buda, J., Pietryka, M., Richter, D., Łokas, E., Lehmann-Konera, S., Makowska, N. \& Bogdziewicz, M. (2018a). Snapshot of micro-animals and associated biotic and abiotic environmental variables on the edge of the south-west Greenland ice sheet. Limnology 19, 141-150.

Crossref Web of Science ${ }^{\circledR}$ Google Scholar

Zawierucha, K., Stec, D., Lachowska-Cierlik, D., Takeuchi, N., Li, Z. \& Michalczyk, Ł. (2018b). High mitochondrial diversity in a new water bear species (Tardigrada: Eutardigrada) from mountain glaciers in Central Asia, with the erection of a new genus Cryoconicus. Ann. Zool. 68, 179- 201.

Crossref Web of Science ${ }^{\circledR}$ Google Scholar

Zawierucha, K., Buda, J., Azzoni, R.S., Niśkiewicz, M., Franzetti, A. \& Ambrosini, R. (2019a). Water bears dominated cryoconite hole ecosystems: densities, habitat preferences and physiological adaptations of Tardigrada on an alpine glacier. Aquat. Ecol. 53, 543- 556.

Crossref CAS Web of Science ${ }^{\circledR}$ Google Scholar 
Zawierucha, K., Buda, J., Fontaneto, D., Ambrosini, R., Franzetti, A., Wierzgoń, M. \& Bogdziewicz, M. (2019b). Fine-scale spatial heterogeneity of invertebrates within cryoconite holes. Aquat. Ecol. 53, 179- 190

Crossref CAS Web of Science ${ }^{\circledR}$ Google Scholar

Zawierucha, K., Buda, J. \& Nawrot, A. (2019c). Extreme weather event results in the removal of invertebrates from cryoconite holes on an Arctic valley glacier (Longyearbreen, Svalbard). Ecol. Res. 34, 370- 379.

Wiley Online Library Web of Science ${ }^{\circledR G o o g l e ~ S c h o l a r ~}$

Zdanowski, M.K., Bogdanowicz, A., Gawor, J., Gromadka, R., Wolicka, D. \& Grzesiak, J. (2017). Enrichment of Cryoconite Hole Anaerobes: Implications for the Subglacial Microbiome. Microbial. Ecol. 73, 532- 538. 